\title{
Building legitimacy: strategic case allocations in the Court of Justice of the European Union
}

\author{
Silje Synnøve Lyder Hermansen*
}

December 25, 2019

\begin{abstract}
Does the President of the Court of Justice of the European Union (CJEU) make strategic use of his members? Cases in the CJEU are prepared by a "judge-rapporteur" who acts as an agenda setter. I argue that the President builds the Court's legitimacy by strategically allocating cases to select judges.

Using original data on 9623 case allocations (1980-2015), I argue that suspicions about judges' political accountability can polarize already politicized debates. The President circumvents such dynamics by appointing a rapporteur whose government holds moderate political preferences. However, he considers governmental preferences and disagreements mainly when case law is not yet developed. This may also contribute to explaining judges' individual-level specialization, which arguably favors the construction of a coherent case law.
\end{abstract}

*I would like to thank Daniel Finke, Andreas Føllesdal, Szilárd Gáspár-Szilágyi, Amie Kreppel, Daniel Naurin, Mark Pollack, Sabine Saurugger, Urska Sadl, Victoria Skeie, Øyvind Stiansen and Geir Ulfstein, as well as four anonymous reviewers for constructive feedback. The data, code and online appendix for the article are available at https: //siljehermansen.github.io/. 
The results speak to the lingering effect of judges' renewable terms - despite secret voting - as well as the importance of courts' internal organization for judicial independence.

\section{Introduction}

Since his appointment by the Bush administration, Chief Justice John Roberts has established a solid voting record among the conservatives on the US Supreme Court. However, in some of the Court's most politicized cases touching questions such as the Affordable Care Act and the right to abortion - he swung the Court towards more judicial restraint than what his and the majority of judges' preferences would indicate.

Commentators have suggested that Roberts relinquished immediate policy gains to maintain the Court's reputation as an institution above politics. While independent courts occasionally go against the wishes of elected leaders, these are moments when they cash in on capital built up as impartial and consistent interpreters of the law. This paper suggests that courts' legitimacy is built by its leadership already at the case-management stage. I look at two under-researched legitimation strategies: attempts to depolarize politicized debates and individual-level specialization as a means to achieve consistency.

Individual decision makers play a central role in the Court of Justice of the European Union (CJEU) and the leadership enjoys a large discretion in assigning it. All cases are prepared by a "judge rapporteur" who acts as an agenda setter. The Court's President derives influence from designating that judge. While he may pursue a policy agenda of his own, the way he manages his staff also impacts the Court's ability to navigate its political environment.

Judges are appointed by their respective governments to six-year renewable terms. The Court is nevertheless among the world's most independent international judiciaries. Its success has inspired the design of many new 
international courts (Alter, 2014). Yet its internal workings have remained unexplored. If who makes decisions within courts matters for the outcome of cases and their reception, then studying how cases and judges are matched is essential to understanding judicial independence.

Judges' accountability to their political appointers is particularly delicate in a politicized environment where suspicions of undue pressure might further polarize decision making. The Court's case management therefore includes several measures intended to ensure judges' independence. All deliberations and votes are kept secret (Dunoff and Pollack, 2017). Similarly, judges do not act as the lead author in cases where they risk striking down their home government's policies. These steps may not be enough, however. I argue that the President is cognizant of the suspicion that judges may be partial. Relying on two different measures of politicization, I demonstrate that the President allocates cases where member states have expressed opposing opinions to judges whose governments occupy a moderate position in the hopes of depolarizing the debate. I further show that considerations of domestic politics mainly spill over to CJEU case management when its case law is not yet developed. The effect then decreases as the Court's interpretation crystalizes.

A coherent case law is a strategy of self-binding in view of future conflicts. While previous research has focused on the effect of specialization on efficiency, I argue that it also alleviates coordination problems among judges and favors coherence within policy domains. Specialization can thus be an asset for power-seeking courts. Yet the CJEU has consistently rejected the practice of specialized chambers established by many other courts (Fabri and Langbroek, 2007). This study shows that the President instead promotes specialization at the individual level and argues that it provides flexibility to make strategic allocation choices. Thus, individual judges are repeatedly made responsible for specific pieces of legislation, while the President retains control over the Court's central players. 
The Court's hybrid nature between an international court and a supranational adjudicator akin to domestic constitutional courts has given rise to a diverse literature on its powers and limitations. Its supremacy in the European judicial hierarchy has induced an overconstitutionalization that undoubtedly constrains governments' policy making (Schmidt, 2018). Yet the Court also moderates its rulings in response to member states' signals (Carrubba et al., 2008; Larsson and Naurin, 2016). Similarly to international courts, its members are politically appointed by national governments (Bobek, 2015; Hermansen and Naurin, 2019) and the member states' executives are its main interlocutors. I consider the CJEU as an international court insofar as its actions are directed towards governments and its judges are assumed to be under the influence of different appointers. However, I draw on the well-established literature on the US Supreme Court to understand case allocation within the judiciary. In both courts, cases are assigned to a lead author whose opinions carry additional weight and whose appointment is done by the leadership.

The paper makes two contributions. First, although voting in the CJEU is kept secret to shield judges from political pressure, I show that division of labor reintroduces elements of accountability that the Court's internal organization seeks to circumvent. Second, the negative relationship between established case law and political considerations indicates that power-seeking courts have an interest in building consistency as part of a legitimization strategy.

\section{Building legitimacy}

Courts enjoy varying levels of diffuse support resilient to the ideological direction of specific rulings (e.g. Gibson and Nelson, 2015). This support rests on a belief that courts are legalistic, impartial and inherently different from the political branches of government (Gibson and Caldeira, 2011). How- 
ever, when decisions are perceived as politically motivated (by ideology or strategy), overall institutional legitimacy decreases (Christenson and Glick, 2015). The public is also more likely to endorse the Court's output merely to the extent that it aligns with their opinions (Bartels and Johnston, 2013). Politically debated cases are therefore moments where onlookers assess and update their beliefs about the Court's legitimacy. A court's diffuse support is thus built up over time. Courts can contribute to this development by cultivating a legalistic reputation through consistent interpretation of the law and by avoiding polarizing already politicized cases.

\section{Impartiality}

When courts are called to resolve questions subject to political debate, they appear as political actors themselves. Judiciaries that enjoy broad discretion should therefore take care when politicized questions are brought before them since they risk being perceived as overstepping their mandate (Ferejohn, 2002).

This is not to say that judges do not pursue an agenda of their own. Case allocation in the US Supreme Court is a top-down process similar to that of the CJEU. The leadership can influence the outcome upstream by appointing the case's agenda setter (Lax and Rader, 2015). The prospect of designating the majority opinion writer thus regularly leads the Chief Justice to strategically change his initial voting choices in order to retain the privilege (Bonneau et al., 2007; Lax and Cameron, 2007; Ura and Flink, 2016). However, whereas the literature on bargaining in the US Supreme Court is centered on internal strategic considerations, the current study focuses on the external political context.

Policy-seeking judges rely on the Court's diffuse support to effectively forward their agenda. This may lead them to exert strategic self-restraint, particularly if they preside over the institution. In the example of Chief Justice Roberts, commentators have suggested that - rather than sacrificing 
his ultimate policy goals - he had opted for an incremental change in the Court's case law. When he was in the minority, Roberts voted in favor of restricting abortion rights ("Hellerstedt", 2016). In contrast, his votes to deny certiorari in "Gee v. Planned Parenthood of Gulf Coast" (2018) and stay restrictions on "Louisiana abortion clinics" (2019) are generally seen as strategic delays awaiting the appropriate occasion to overturn precedent. If so, he restrained himself because the Court was in an exceptionally powerful position and would be perceived as unduly political.

This study remains agnostic as to the President's policy preferences, but assumes the belief that his favored policies become more effective as the Court's legitimacy increases. That support is built already at the casemanagement stage. Although appropriate decision making cannot in itself legitimize the outcome, criticism of the process suffices to undermine it (Schmidt, 2013). In other words, judgments may be discredited merely by the way they are decided. This may lead the President to select adjudicators who are acceptable to a wider range of actors in instances where the Court's output may lead to controversy.

Judges' perceived impartiality is key to effective adjudication. When they are politically appointed and have renewable terms, their impartiality may come under scrutiny (Voeten, 2008; Shepherd, 2009a,b; Elsig and Pollack, 2014). The preferences of governments thus reflect upon their judges. Regardless of whether pressure is in fact exerted, such suspicions reduce the legitimacy of the process. The impression applies equally to all adjudicators within an institution, but when decision making is collective, heterogeneity in the membership ensures some degree of checks and balances (Kelemen, 2012).

In contrast, when only a few members play a key role, the outcome sometimes changes (Spirig, 2019). Onlookers may thus suspect that judges' career concerns influenced the decision and be tempted to let their ideological congruence with the decision makers' government taint the assessment. 
When matching cases with judges, it is therefore beneficial to avoid delegating politicized tasks to judges whose appointers are polarizing.

\section{Consistency}

Courts are set up to reduce the legal uncertainty inherent in all legislation and they draw legitimacy from fulfilling that purpose. However, such uncertainty also makes room for policy-oriented considerations. First, judges may willingly or unwillingly rely on their attitudes to guide interpretation. Second, external political actors may see it more beneficial to pressure the court when uncertainty is high.

Judicial policy making is an iterative process by which judges repeatedly - and in the concrete - crystalize a set of rules (Lax, 2007). Uncertainty will typically be highest the first time a law is brought before a court and decreases with each interpretation. This has two implications. First, the political stakes are higher the first time a court interprets a legal text. Second, a coherent case law is a central attribute for courts in search of legitimacy. It maintains the fiction that judicial decision making is merely technocratic (Burley and Mattli, 1993). Moreover, reducing uncertainty also reduces transaction costs for societal actors, thereby helping the court to fulfill its purpose (Pollack, 2003). Stated differently, a cohesive case law im-

poses a future cost on decision makers who seek to overturn extant practice, be it the Court itself or external political actors (Garrett et al., 1998).

Cohesiveness may nevertheless lead to coordination problems among judges. Although there is an expectation that precedent guides judicial decision making (Knight and Epstein, 1996), members also frequently overlook extant case law (Segal and Spaeth, 1996). Judges vary in their policy preferences, but also in their propensity to follow doctrine (Bailey and Maltzman, 2008). Relevant knowledge relating both to a case's policy domain and to the Court's earlier decisions also varies among members. Heterogeneity in judges' attributes adds to the complexity of deliberations and risks leading to inconsistent out- 
comes.

One way to promote consistency within a policy domain is to ensure specialization. Specialization provides the expertise needed to efficiently handle a substantial case load while still rendering high-valence judgments (Lax and Cameron, 2007). Yet, the CJEU has continued to reject the notion of specialized chambers arguing that it would lead to parochial decision making. Even sector-specific cases may touch upon horizontal issues or foundational principles of EU law. Such matters should not be left to a subset of policy experts (Prechal, 2015, p. 1286-1287). The argument has parallels to the literature on the US Congress where committee-level specialization is sometimes presented as a means for log-rolling among policy makers with diverse preferences (e.g., Shepsle and Weingast, 1994). However, policy outcomes in this system would not reflect the preferences of the median member along any unified policy dimension. Rather, specific policies would be defined by high demanders, and budgets would be unbalanced. In a court, this would lead to inconsistent outcomes across policy domains. Krehbiel (1992) alternatively suggests that policy making is a case of imperfect information. Allowing members to specialize and share information increases the institution's decision-making capacity, but the plenary needs a way to control the outcome. As a monitoring mechanism, committees must therefore be heterogeneous. While the literature on Congress has focused on the plenary's ex post control mechanisms, the literature on the US Supreme Court has also highlighted the value of individual-level specialization at the case-allocation stage. As such, substantive expertise is a consistent predictor of majority opinion assignments in the US Supreme Court (e.g., Wahlbeck, 2006). When the same types of cases are repeatedly matched with the same decision maker, consistency is more likely within that policy domain. The case-to-case approach further allows for two control mechanisms: the President remains free to allocate specific cases to the judges he deems most fit while all rapporteurs are monitored by a heterogeneous chamber of judges. 


\section{The CJEU - matching judges with cases}

Courts vary along two dimensions. Deliberations may be more or less inclusive, and allocations may be more or less left to the membership's discretion. In most courts, at least some part of the information collection and drafting of judgments is done by a single judge. Both the CJEU and the European Court for Human Rights (ECtHR) have inherited their reliance on "judgerapporteurs" from the French judicial system. In other countries, judgments are drafted by a member of the majority after an initial discussion of the case (e.g. the US Supreme Court). In all of these examples, the delegation is done by the leadership.

Here, I argue that the President of the CJEU's most important task is to match judges with cases and that the identity of the appointee matters.

\section{The judge-rapporteur is an agenda setter}

The involvement of judges varies depending on the institution and the stage of the process (e.g. Dunoff and Pollack, 2018, p. 101-102). Courts with a high case load will typically strive to divide labor, effectively increasing individuals' influence and visibility. Even when voting is secret, the identity of the agenda setter may not be. When terms are renewable, this can reintroduce elements of accountability.

The ECtHR provides an interesting point of comparison. Both courts rely on a "judge-rapporteur" to prepare cases and draft the final judgment. However, their institutional setting is diametrically opposite. In the CJEU, judges' terms are renewable but no dissenting opinions are made public (RoP, 2012, Article 32). The rapporteur nevertheless signs the judgment and his name is published together with the text (Guide Pratique, 2017, Title IX(95)). Thus, although secret deliberations aim to protect judges from accountability (Dunoff and Pollack, 2017), the identity of the decision makers is disclosed. One reason may be that the rapporteur is appointed prior 
to the panel's first meeting and remains the same throughout the process. In other words, the rapporteur does not formally represent the majority of judges, but rather the panel as such.

In contrast, the ECtHR allows for dissenting opinions but has introduced term limits. This may not be enough to guarantee the independence that the Court seeks, however. The rapporteur in the ECtHR occasionally steps down as a result of divergent opinions. By threatening to resign, he can gain additional bargaining leverage. It is not surprising, then, that the rapporteur's identity remains unpublished and that practitioners have called for greater protections against retaliatory actions (e.g. Keller and Meier, 2017). The example illustrates that the identity of the rapporteur is sensitive because of the influence he has, and not merely due to the views he holds.

While research on the influence of the rapporteur in the CJEU is scarce, the internal guidelines for case management leave room for the rapporteur to frame the debate. In other words, the rapporteur acts as an agenda setter at different stages in the process (Saurugger and Terpan, 2017, p. 53).

In the highest formation of the CJEU the rapporteur is appointed at the outset, and the assignment of other panelists follows from the appointee's chamber affiliation (Guide Pratique, 2017, Title(IV)31). This stands in contrast to the ECtHR and the lower formation of the CJEU where cases are allocated directly to chambers before the rapporteur is assigned by the chamber president. Early in the case, the rapporteur communicates a preliminary report to the plenary meeting (RoP, 2012, Article 59). This report offers suggestions for how to deal with the case and enumerates the key questions involved, and it may go far in outlining the outcome. The size and composition of the panel of judges is determined in this meeting. In parallel to the President's appointment of a rapporteur, the First Advocate General appoints an advocate general to flank the judge preparing the case. The advocate general is tasked with presenting the case in all its aspects in the absence of dissenting opinions and is often seen as a second agenda setter 
(e.g. Frankenreiter, 2018a). The plenary meeting decides whether such an opinion is required. The meeting is normally the first and last time most members see the case (Guide Pratique, 2017, Title IV(41)). It is a moment of coordination and collective control where members can flag related cases. However, the rapporteur acts with considerable autonomy already at this stage. Although the typical meeting agenda includes 15-20 cases, only a subset of them are subject to debate. A substantive debate often only occurs if the rapporteur and advocate general disagree.

The rapporteur also has a prominent role during the oral hearing. Fifteen years ago, judges frequently came unprepared and did not pay particular attention. However, the hearing has grown in significance since the use of an advocate general is no longer mandatory. The proceedings begin with questions asked by the rapporteur. The questions can sometimes provoke reactions from the parties and can appear to reveal the author's leanings. A substantive discussion takes place only later. In the absence of an advocate general, a short roundtable is organized before the rapporteur produces a memo. In contrast, if an advocate general is assigned to the case, the discussion is postponed for several months pending his report. This does not prevent the rapporteur from sometimes drafting a proposal without the advocate general's formal input.

The final deliberations are based on the rapporteur's draft. All judges are requested to present their views and if no consensus is reached, the outcome is decided by a majority vote. There is no mechanism to ensure that the rapporteur adheres to the majority decision. However, as the lead author of the case, he is tasked with formulating the legal argument. Rapporteurs are typically more likely to cite earlier cases written by other rapporteurs whose appointing governments hold similar views to their own (Frankenreiter, 2017).

Given his central role, we may assume that the rapporteur's appointment is key to the institution's policy making. In courts where case assignment is 
discretionary, we may expect the choice to be strategic.

\section{Allocations are at the President's discretion}

Courts also vary in how much discretion they enjoy in assigning cases. The leadership's ability to strategically adjust allocations is therefore a question of institutional design.

Some courts follow a completely random case assignment (e.g. the US appelate courts), whereby the leadership controls neither the combination of judges nor the match between judges and cases. Other courts follow a system of administrative case assignments. Typically, panel compositions are predetermined, while cases are assigned following a rotation. This solution is used in several international courts. One reason may be that the system ensures some degree of representation among the decision makers. For example, chambers in the ECtHR reflect the different legal systems as well as ensuring geographical and gender balance (ECtHR, 2018, Rule 25-1 and 2). Similar considerations apply informally in the CJEU. In addition to the principle of rotation, some courts also include specific rules pertaining to the match between judges' and parties' nationalities. All signatories of the ECHR are therefore guaranteed representation by their own appointed judge (ECtHR, 2018, Rule 26). These rules let states influence the checks and balances in the deliberations. However, even when chamber assignments are left to the courts, they tend to produce more ideologically heterogeneous panels than what a random draw would indicate (Gschwend et al., 2016; Frankenreiter, 2018b).

Yet other courts allow for discretionary case allocations exercised collectively and/or by the court's leadership. The Court of Justice, constitutes an example of extreme leadership discretion. The President is free to designate the rapporteur of his choice with one exception: Since the Court's inception, no judge has acted as rapporteur in infringement cases brought against his own government. Following the Nice treaty (2003), the President has also 
consistenly followed the same principle for preliminary references.

A relevant question is how much information the President has before making the delegation. Although, a rapporteur is named as soon as possible after the case is lodged (RoP, 2012, Article 15.1), this is only done upon the reception of additional information provided by the administration (Guide Pratique, 2017, Section I(9-11)).

Following the lodging, the Registry prepares a preliminary memo. The document briefly describes the case and identifies similar cases and their authors - past or present - in order to facilitate allocation decision (Guide Pratique, 2017, Section I(1 and 11)). Additionally, under the preliminary reference procedure, the Research and Documentation Directorate proceeds to a more thorough "pre-examination." The document is authored by one of the Court's civil servants with local expertise and provides contextual information. It identifies the relevant national and European laws as well as related case law. It may further include information on dissenting opinions, observations filed by the public prosecutor or debates on jurisprudential or doctrinal questions at the domestic level. The list is not exhaustive (Guide Pratique, 2017, Section I(4-5)).

With this information in hand, the President proceeds with the appointment (Guide Pratique, 2017, Section I(9-11)).

\section{Empirical expectations}

I assess two strategies that build the Court's reputation as a predictable and impartial interpreter of the law: specialization and depolarization.

A coherent case law can be seen as a self-binding strategy in view of future conflicts. Researchers have noted, for example, that the Court refers to a larger body of earlier decisions when it rules against the majority of member state observations than when the political environment is less hostile (Larsson et al., 2017). These arguments are built up in a series of consistent 
judgments prior to the conflict. Although the early steps of the case management provide information, the judges may still differ both in their level of knowledge and their political orientations.

Coordination problems are common in all decision-making bodies. Courts' internal organization therefore involves several measures to ensure consistency. It is useful in this respect to distinguish between consistency within and across issue areas. Specialization is a way of favoring coherent decision making within policy areas. However, chamber-level specialization poses a particular threat across domains. Since the Nice treaty (2003), the default decision-making mode of the Court has been chamber deliberations. To compensate for the potential fragmentation of case law, both the administration and the general meeting are tasked with identifying related cases. For the same reason, each chamber president sits on all cases treated by their chamber.

Even an individual-level specialization involves a potential delegation problem for the Court. Highly specialized members can selectively transmit information to the other judges and trick them into favoring outcomes they would not otherwise have opted for (Fischer and Stocken, 2001). In the parliamentary context, Chiou et al. (2020) have demonstrated that such specialization yields diminishing marginal returns. The leadership tends to prefer specialized members to generalists but when the gap between members' specialization is sufficiently large, the most expert member may not necessarily be favored. The institution thereby builds up a pool of alternative experts on a topic. I therefore expect the President to promote specialization by repeatedly delegating the same types of cases to the same judges but the effect decreases over time.

Hypothesis 1 The President is more likely to appoint a rapporteur who has acted in the same role in previous cases related to the same topic.

Courts benefit from a reputation as apolitical and impartial decision makers. However, the division of labor implies that the rapporteur is easily 
identified as an agenda setter. Furthermore, EU judges sit for renewable terms and are politically appointed. The preferences of a rapporteur's current government may therefore reflect upon the judgment. When member state governments have expressed diverging opinions, the President may be careful not to polarize debates further by appointing judges whose governments hold an extreme position. Consequently, I expect that the President would identify potentially politicized cases and avoid judges whose government would further accentuate the divide.

Hypothesis 2a In cases where member states have expressed conflicting positions, the President is less likely to appoint a judge whose current government holds preferences far from the median.

Politics are the most salient when the legal uncertainty is pronounced. Since case law is typically built up over time (Lax, 2007), it means that the first time a legislation reaches a higher court, the potential for political input is more substantial. Assuming the Court's case law has a constraining effect on political actors, I expect that the President would assess the risk of politicization as decreasing for each interpretation of a particular law. The effect of government preferences would thus decrease over time.

Hypothesis $\mathbf{2 b}$ The effect of governmental preferences in cases where governments disagree decreases with the number of interpretations the Court makes of the same law.

Overall, I expect specialization to be a consistent predictor in most allocations, while the effect of governments' political preferences pertains to a subset of cases where governments have expressed disagreement and there is significant legal uncertainty. 


\section{Empirical strategy}

In the following, I describe the basic structure of the data and justify my choice of model before giving an account of my operationalizations.

\section{Data structure and choice of model}

To better understand the President's allocation criteria, I have collected data on 9623 court cases (1980-2015). Its structure provides a realistic description of the alternatives faced by the President. For each case, I list the judges who were members of the Court. This constitutes the President's "choice set." The baseline data frame thus includes 217069 observations of a total of 86 judges nested in cases, while the dependent variable is an indicator of the Rapporteur in each case.

The statistical model is guided by the same realism. All results are obtained from mixed conditional logistic regression. The probability that a case $j$ is allocated to justice $i$ can be written as follows:

$$
\mu_{j(i)}=\beta X_{j(i)}+\beta X_{j(i)} \times Z_{j}
$$

The choice calls for some clarifications. First, the Court's membership evolves continuously, presenting the President with an ever-changing menu of judges from which to choose. This variation makes comparisons over time challenging, as the level of the predictors is substantially different. In the conditional logit model, irrelevant alternatives are excluded. The overall levels of measurement of the variables may well vary across cases, but their effect is aggregated and correctly estimated (Long, 1997, p. 178).

Second, while most predictors $\left(X_{j(i)}\right)$ describe differences between judges nested within choice sets, I expect that the President's assessment also depends on contextual features that vary at the case level $\left(Z_{j}\right)$. Specifically, I 
expect the selection criteria to change in politicized cases. These predictors are included as cross-level interactions. The model hence qualifies as a mixed conditional logit model.

All results are obtained using MCMC simulation within a Bayesian framework. More detail is provided in the Online Appendix.

\section{Variables}

Regardless of the type of case filed, I expect the President seeks to build coherence through specialization $\left(H_{1}\right)$. In addition, I expect the preferences of a judge's member state will have a bearing on allocations in potentially politicized cases $\left(H_{2}\right)$.

\section{Consistency through specialization}

I rely on two different measures of specialization at the time of the allocation.

Specialization - overlap in affected legislation captures the overlap between legal texts - treaties and secondary acts - directly affected by the litigation. To construct the variable, I compare each case with all previous cases in a judge's portfolio as rapporteur. For each pair of cases, I thus calculate the proportion of overlap, before summing over the entire portfolio. In most instances (73\%), the President has at least one judge at his disposal who has previously rendered a judgement affected by the same EU laws.

Specialization - overlap in topics is constructed in the same way, but captures the overlap between the 55 policy areas identified by EUR-Lex. Throughout a judicial career, a judge is the institution's most specialized member in $3 \%$ of the allocations on average. However, the President will almost always have at least one member with some related experience (99.77\%).

The asymmetry works in the President's favor, since the spread in related experience means there are generally other alternatives to choose from. This is, of course, the product of the President's (or his predecessor's) earlier 
allocations and a result of diminishing marginal returns on specialization. In contrast to previous studies, this study uses a continuous measure (e.g. Wahlbeck, 2006). To reflect the President's fear of agency drift, the variable is $\log$ transformed $(\log (x+1))$. It expresses the expectation that the President prefers the most specialized member when there is little difference between judges but then chooses the most expert member less frequently as the gap increases.

\section{Avoiding polarization of controversial cases}

The President will avoid polarizing cases that are already controversial $\left(H_{2 a}\right)$. I rely on two measures where governments have expressed different preferences.

Potential politicization - new debated legislation relies on all cases affecting secondary legislation that passed through the Council (1980-2016). If a proposal can be resolved by national civil servants, the dossier passes without discussion as an "A-item" on the Council's agenda. In contrast, a "B-item" reflects legislation with sufficient political disagreement to vouch for a discussion among ministers (e.g., Wøien Hansen, 2014). When such legislation is brought before the Court for the first time, I expect the President anticipates some degree of politicization. Such cases are relatively rare. In total, I have identified 463 out of 2813 judgments (16\%) affecting B-item legislation where the text has not yet been interpreted by the Court.

In $H_{2 b}$ I specifically test the argument that cases are more prone to politicization when the legal uncertainty is great. I assume that uncertainty decreases each time the Court interprets a law. Potential politicization - iteration before the Court therefore reports the $n^{\text {th }}$ interpretation that the Court makes of a debated piece of legislation.

Potential politicization - diverging member state observations indicates whether the Court received amici curiae briefs from at least two governments

expressing different preferences over the outcome. Roughly half (60\%) of the 
Courts cases are preliminary references, where judges are called to determine the compatibility of EU and national law with the treaties. Member states are invited to submit their observations within two months of being notified (Statutes of the Court, 2012, Article 23). While the President may not yet have read these observations at the time of the allocation, he likely has other sources of information that I, as a researcher, do not. In the second operationalization, I therefore rely on information from these observations. The data is obtained from two handcoded sources which do not, unfortunately, cover my entire period of study (Carrubba and Gabel, 2011; Carrubba et al., 2008, cases lodged from 1980 to 1996; Larsson and Naurin, 2016, from 1996 to 2008).

Following $H_{2 a}$, I expect the President to take government preferences into account only when governments have expressed disagreement. The indicators of politicization are therefore interacted with a measure of governments' economic preferences to assess whether the effect of preferences is conditional on the Court's political context. I expect a negative sign. The choice of an economic scale is closely linked to the measure of politicization. The Court is called to clarify policies on which governments in the Council have expressed their disagreement. The left-right cleavage is a dominant dimension in the EU legislative process (Crombez and Hix, 2015). Economic preferences are also the most salient policy dimension in domestic politics. The CJEU has furthermore been a driver of European economic integration and its rulings can constrict governments' ability to formulate economic policies. This also spills over to the judges' careers. Governments with different economic preferences tend to appoint different judges, while no such relationship is observable for variation on the EU-integration dimension (Hermansen and Naurin, 2019).

Distance from median government therefore reports the absolute difference in preferences on economic issues between a judge's current government and the median among members on the bench. Preferences are calculated as a 
weighted mean derived from the current ruling parties' electoral manifestos using the vanilla method (Döring and Manow, 2018; Volkens et al., 2017; Gabel and Huber, 2000). Cabinet-share weighted manifesto scores have previously been used to assess judges' ideal points along a left-right dimension (Malecki, 2012). The measure places governments in the same policy space. In practice, most observations $(99 \%)$ are registered with a distance ranging between 0 and 1 . In the model, the measure is $\log$ transformed $(\log (x+1))$ to limit the influence of extreme outliers on the overall effect.

\section{Controls}

The models include controls for members who are a priori unlikely to act as rapporteur. Ties to member state - case from judge's member state indicates if the case originated in the judge's member state. The President only acts as rapporteur in the rare event of a full-court sitting. He is therefore excluded from the choice set. Similarly, Leadership indicates presidents in chambers of five judges (since 2003) and the Court's Vice-President (since 2012). These are positions which, in recent years, have become more managerial. Last, Membership unclear indicates judges whose membership at the Court is uncertain because they are at the beginning or end of their mandate. It may be unclear to the President whether the case will conclude before the end of the judge's mandate. Similarly, new judges need time to adjust to the environment in Luxembourg (Cheruvu, 2019) and may therefore not be considered for reports.

Participation counts the number of panel deliberations a judge has attended the last 90 days. Judges' vary in how invested they are in their mandate and what career stage they are at. This is reflected in their participation rates. In the median choice set, the inter quartile range among members is 8 deliberations. I expect that assiduous members would be more likely to be appointed.

Similarly, all models control for the number of Past cases in which a judge 

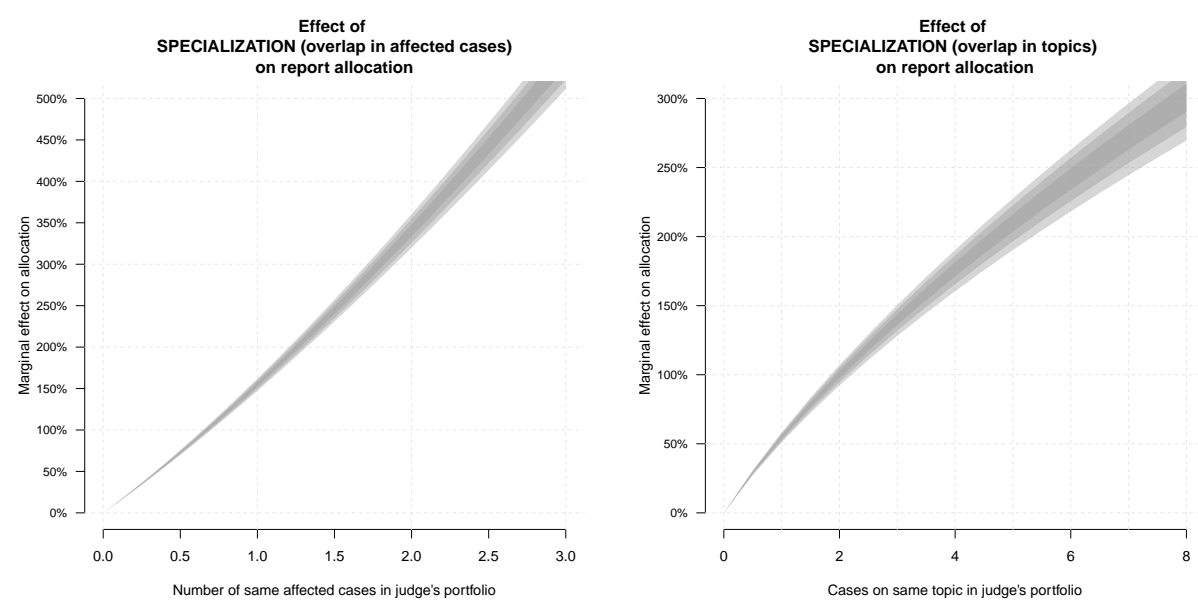

Figure 1: The effect of relative expertise acquired from previous cases on the same topic on case allocation.

has acted as rapporteur. The measure can be seen as a lag of the dependent variable, subsuming all other reasons why the President may prefer one judge over another. Once again, the variation is substantial, with the median choice set displaying an inter quartile range of no fewer than 82 cases. In the multivariate analysis, the variable captures a member's experience with unrelated cases. If the President favors specialization, I expect it to correlate negatively with the likelihood of an appointment.

\section{Results}

Constructing coherence through specialization $\left(H_{1}\right)$ Results from a first series of regressions are displayed in Table 1 and further illustrated in Figure 1. The limits of the 95\% highest posterior density interval are reported in parentheses and can be read as confidence intervals. We see a strong and consistently positive effect of specialization across the two operationalizations.

When the Court has already interpreted the legislation, a judge who has 


\begin{tabular}{lcc}
\hline \hline Dependent variable: 'Allocation of report' & Overlap in legislation & Overlap in topics \\
\hline Specialization (H1) & 1.378 & 0.656 \\
& $(1.343,1.412)$ & $(0.626,0.685)$ \\
Ties to member state (case from MS) & -1.45 & -1.445 \\
Cases as rapporteur & $(-1.567,-1.295)$ & $(-1.586,-1.311)$ \\
Membership unclear & -0.248 & -0.48 \\
& $(-0.271,-0.234)$ & $(-0.506,-0.451)$ \\
Participation & -0.924 & -0.982 \\
& $(-1.023,-0.834)$ & $(-1.071,-0.889)$ \\
Leadership (Chamber/Vice president) & 0.045 & 0.045 \\
& $(0.042,0.047)$ & $(0.043,0.048)$ \\
& -0.489 & -0.542 \\
Number of observations & $(-0.563,-0.416)$ & $(-0.628,-0.469)$ \\
Number of choice sets & 217284 & 217284 \\
Proportion of correct predictions & 9949 & 9949 \\
Prop. of correct positive pred. & & \\
Prop. of correct negative pred. & 0.65 & 0.597 \\
& 0.613 & 0.643 \\
Median effects with 95\% symmetric posterior density interval in parenthesis.
\end{tabular}

Table 1: The effect of SPECIALIZATION on allocation of court cases. Results from a hierarchical conditional logit.

acted as rapporteur once before is more than 1.6 times as likely to act as a rapporteur again compared to a colleague with no such experience. When considering the median distance between the most specialized and the least specialized judges in a choice set (an overlap of 1.5 cases), the likelihood of an appointment is 2.5 times higher for the expert.

The effect is equally substantial for cases related by their subject matter. For each related judgment, a member sees his likelihood of appointment increase by $58 \%$ compared to a judge with equivalent but unrelated experience. When considering the median difference between the most and the least specialized member (an overlap of 26 cases), the effect is consequential: The most specialized judge is 7.6 times more likely to be appointed.

The results show how individual judges play a central role in formulating the Court's policies deriving from specific pieces of legislation and within policy areas. However, the shape of the curve in the right panel of Figure 1 also indicates that specialization in a subject matter yields diminishing returns. 
The President does not consistently favor the most specialized member. As the distance between the judges increases, he discriminates less according to specialization. We can understand this through the lens of agency drift. The case-to-case approach means that the President can move to compensate as other judges' ability to monitor or supplement a rapporteur decreases. This flexibility also means that the President can occasionally prioritize other selection criteria without making substantial tradeoff with specialization.

Avoiding policy outliers when cases are politicized $\left(H_{2}\right)$ Table 2 displays results from a second series of regressions testing the effect of preferences in politicized cases. This time, the measures of specialization are included as controls. Once again, the results are as expected.

As is apparent from Figure 2, both operationalizations of politicization indicate a significant shift towards rapporteurs with a government close to the median $\left(H_{2 a}\right)$. If we consider the median most extreme outlier that the President could potentially choose (i.e., a median absolute distance of 0.66), his chances of allocation would decrease by $44 \%$ if the affected legislation had been subject to political bargaining and the Court had not yet made an interpretation. The similar figure is $30 \%$ when politicization is measured as disagreement expressed in the case at hand. Preferences are also relevant for judges from more moderate governments. If we consider the typical distance between judges on the Court (an interquartile range of 0.13 ), we still see a decrease of $13 \%$ when disagreement is expressed at the legislation phase, and $8 \%$ when disagreement surfaces during the case.

The results indicate that the President is sensitive to government preferences when allocating politicized cases. I have argued that this is due to the member states' suspicion that judges could take cues from their home government. A controversial choice of judge in cases where governments already disagree would unnecessarily polarize the Court's decision. The President seeks to avoid that. Depolarization is important because the Court's legit- 
imacy increases when its decision making is perceived as apolitical. It is worth noting, however, that these political considerations only spill over to the allocations in a subset of Court cases. As the left column in Figure 2 illustrates, government references do not have an effect when cases are not politicized.

The results also speak to the importance of coherence. A consistent case law allows the Court to build support for a line of interpretation. It also means that the President should expect less political debate in subsequent cases. This is reflected in the decreasing sensitivity to governments' preferences as the Court repeatedly interprets the initially debated legislation.

The second interaction reported in Table 2 tests the idea that the President believes cases are more likely to become politicized when the Court's interpretation is uncertain $\left(H_{2 b}\right)$. Figure 3 illustrates the hypothetical example of the median most extreme outlier when an allocation pertains to debated legislation. The figure makes clear that the importance of governmental preferences decreases as the Court's interpretation of the law becomes established. By the fifth iteration, the chances a judge from a policy outlier being appointed is indistinguishable from that of other members.

\section{Conclusion}

Courts' legitimacy is built starting from the case-management stage. Although an orderly process is not enough to legitimize a court's output, criticism of the process suffices to sink it. The Court of Justice of the European Union enjoys extensive internal autonomy, and I have investigated two of its strategies to build legitimacy. Cases are allocated by the Court's President, and I have found that his choice is sensitive to the judiciary's political environment. Because polarization is detrimental to the Court, he allocates potentially politicized cases to judges from moderate member states. I also

found that the effect of government preferences decreases once the Court 

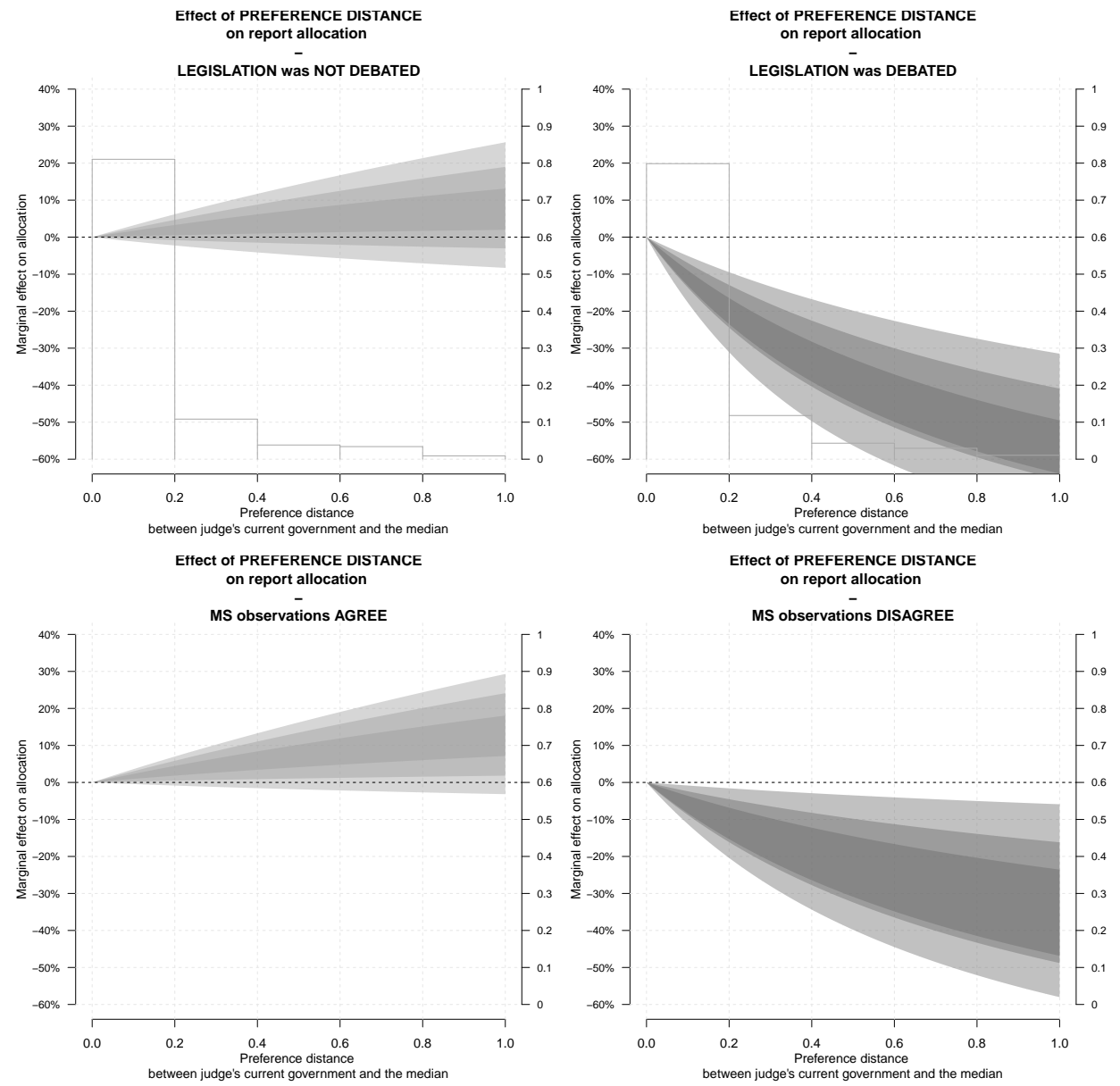

Figure 2: The conditional effect of politicization: The figures illustrate the effect of distance between a judge's current government and the median government currently in power on the probability of case allocations. 
Effect of

ITERATIVE INTERPRETATION

of DEBATED legislation

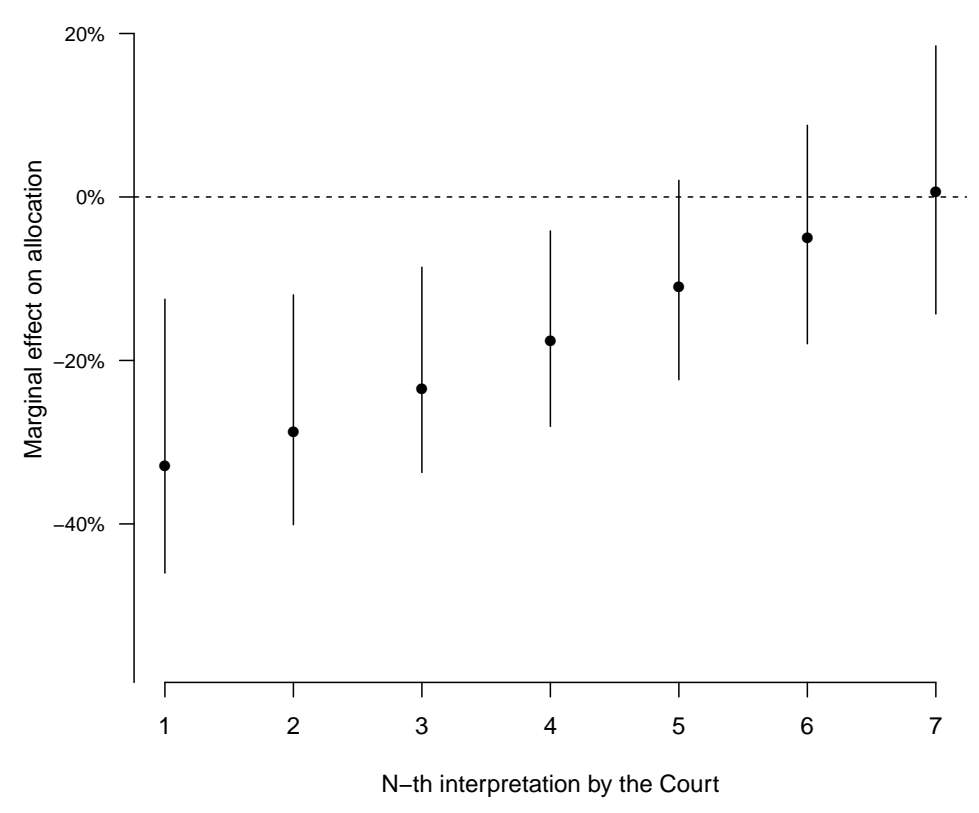

Figure 3: The figure illustrates the predicted effect of the Court's iterative interpretation of politicized legislation among judges from the (median) most outlying governments. 


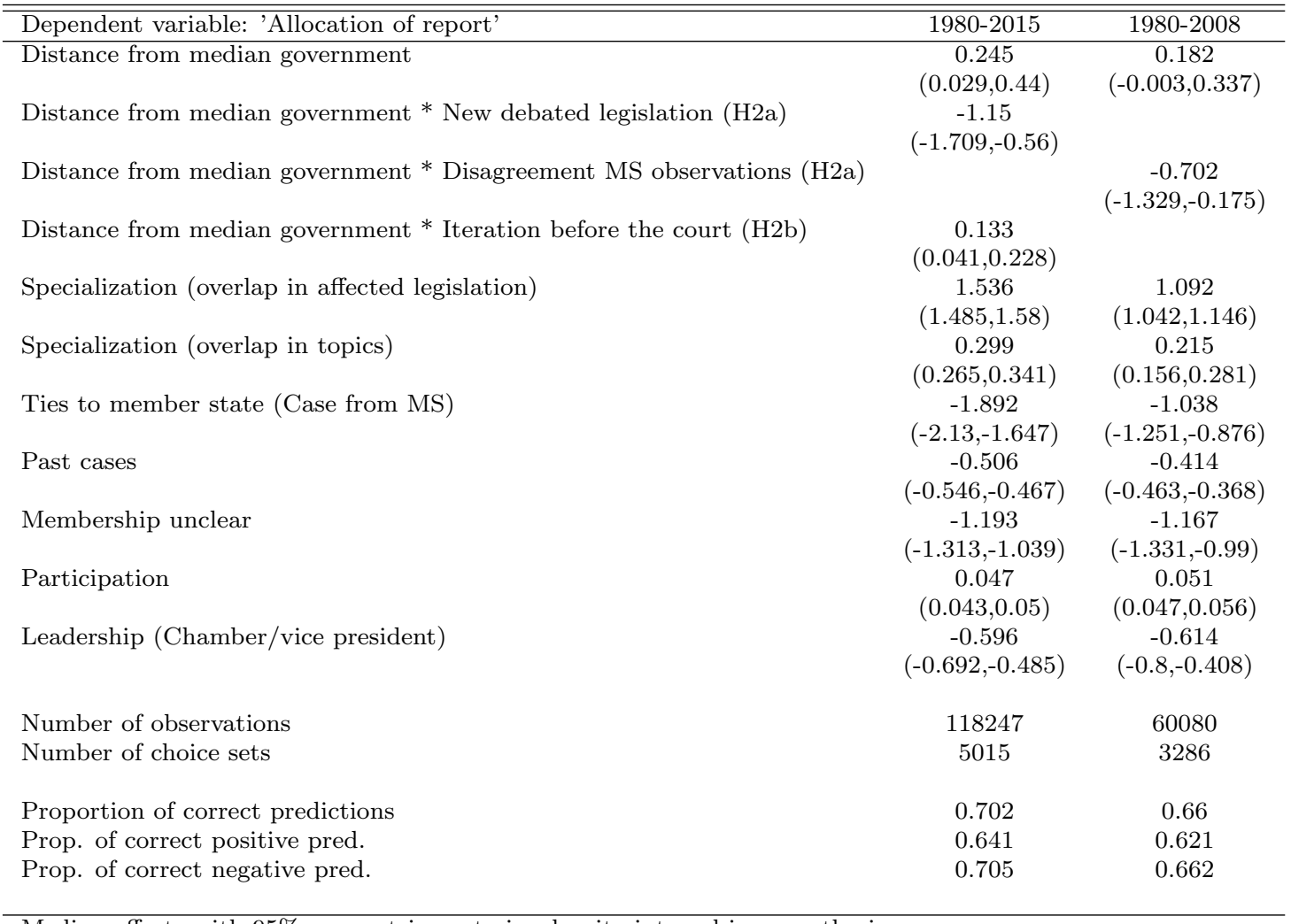

Median effects with $95 \%$ symmetric posterior density interval in parenthesis.

Table 2: The effect of the current government's preferences on allocation of preliminary reference cases. Results from a hierarchical conditional logit.

has established its' case law. This is because politics are the most salient when legal uncertainty is great. A clear precedent imposes a cost on decision makers who seek to overturn it and is therefore valuable to powerseeking courts. However, coherent decision making also implies coordination problems among judges with diverse motivations. While chamber-level specialization promotes consistency within a policy domain, it also limits the President's discretion. This study demonstrates that the CJEU instead promotes individual-level specialization and argues that it provides the flexibility required to make strategic allocations.

The results shed new light on the preconditions for international courts' 
independence. First, I demonstrate that the Court's political context spills over to the allocation of influence among judges and link it to their potential accountability. Extant literature highlights two alternative means of preventing sanctions against individual judges. The sanction itself can be removed or a government's ability to impose it meaningfully can be curtailed by reducing transparency. Thus far, studies have focused mainly on the effect of renewable terms and information on judges' voting (Dunoff and Pollack, 2017). However, removing these elements may not be enough to ensure onlookers of the adjudicators' impartiality. Other types of retaliation or information may also be relevant. I focus on information on judges' role as agenda setters and suggest that it reintroduces elements of accountability that secret voting seeks to prevent. The comparison with the European Court of Human Rights furthermore shows that even when terms are non-renewable and dissents are public, the court may still choose not to disclose the identity of the judge rapporteur. I conclude from this that the rapporteur is a central player in the Court's decision making and information regarding his identity can be sensitive.

Second, I have demonstrated that the Court's internal organization gives it agency. The President can take additional steps to build up expertise or prevent backlash against judges. Thus, judges never act as rapporteurs in cases involving their own government.

Member states may be tempted to constrict international courts' autonomy to organize their work by imposing national quotas among decision makers. Yet, as long as judicial appointments are political and judges do not have life tenure, the current governments' preferences reflect upon their appointee. This is a limited problem when decision making is collective, as different judges hold each other in check. However, many international courts have addressed their increasing case load by dividing labor. Even when voting is secret, the agenda setters may be identifiable and their impartiality put under scrutiny. A random case allocation would regularly lead 
to matches between judges and cases that would unnecessarily polarize the Court's decision making.

\section{References}

Alter, K. J. (2014, January). The New Terrain of International Law: Courts, Politics, Rights. Princeton University Press.

Bailey, M. A. and F. Maltzman (2008, August). Does Legal Doctrine Matter? Unpacking Law and Policy Preferences on the U.S. Supreme Court. American Political Science Review 102(3), 369-384.

Bartels, B. L. and C. D. Johnston (2013). On the Ideological Foundations of Supreme Court Legitimacy in the American Public. American Journal of Political Science 57(1), 184-199.

Bobek, M. (Ed.) (2015, March). Selecting Europe's Judges: A Critical Review of the Appointment Procedures to the European Courts.

Bonneau, C. W., T. H. Hammond, F. Maltzman, and P. J. Wahlbeck (2007, October). Agenda Control, the Median Justice, and the Majority Opinion on the U.S. Supreme Court. American Journal of Political Science 51(4), 890-905.

Burley, A.-M. and W. Mattli (1993). Europe Before the Court: A Political Theory of Legal Integration. International Organization 47(1), 41-76.

Carrubba, C. J. and M. Gabel (2011, July). European Court of Justice Data.

Carrubba, C. J., M. Gabel, and C. Hankla (2008, November). Judicial Behavior under Political Constraints: Evidence from the European Court of Justice. American Political Science Review 102(4), 435-452. 
Cheruvu, S. (2019). How do institutional constraints affect judicial decisionmaking? The European Court of Justice's French language mandate. European Union Politics 20(4), 562-583.

Chiou, F.-Y., S. S. L. Hermansen, and B. Høyland (2020). Delegation of Committee Reports in the European Parliament. European Union Politics, 1-22.

Christenson, D. P. and D. M. Glick (2015). Chief Justice Roberts's Health Care Decision Disrobed: The Microfoundations of the Supreme Court's Legitimacy. American Journal of Political Science 59(2), 403-418.

Court of Justice of the European Union (2012, September). Rules of Procedure.

Court of Justice of the European Union (2017, October). Guide Pratique Relatif au Traitement des Affaires Portées devant la Cour de Justice.

Crombez, C. and S. Hix (2015, July). Legislative Activity and Gridlock in the European Unioneffect beyond their impact on the gridlock interval. The st. British Journal of Political Science 45(3), 477-499.

Döring, H. and P. Manow (2018). Parliaments and Governments Database (ParlGov): Information on Parties, Elections and Cabinets in Modern Democracies.

Dunoff, J. L. and M. A. Pollack (2017, April). The Judicial Trilemma. American Journal of International Law 111(2), 225-276.

Dunoff, J. L. and M. A. Pollack (2018). A Typology of International Judicial Practices. In A. Follesdal and G. Ulfstein (Eds.), The Judicialization of International Law - A Mixed Blessing? (1 ed.)., European Society of International Law Series, pp. 86-106. Oxford: Oxford University Press. 
Elsig, M. and M. A. Pollack (2014, June). Agents, trustees, and international courts: The politics of judicial appointment at the World Trade Organization. European Journal of International Relations 20(2), 391-415.

European Court of Human Rights (2018, April). Rules of Court.

Fabri, M. and P. M. Langbroek (2007). Is There a Right Judge for Each Case - A Comparative Study of Case Assignment in Six European Countries. European Journal of Legal Studies 1, 292-315.

Ferejohn, J. (2002, July). Judicializing Politics, Politicizing Law. Law and Contemporary Problems 65(3), 41-68.

Fischer, P. E. and P. C. Stocken (2001). Imperfect Information and Credible Communication. Journal of Accounting Research 39(1), 119-134.

Frankenreiter, J. (2017). The Politics of Citations at the ECJ-Policy Preferences of E.U. Member State Governments and the Citation Behavior of Judges at the European Court of Justice. Journal of Empirical Legal Studies 14(4), 813-857.

Frankenreiter, J. (2018a). Are Advocates General Political? An Empirical Analysis of the Voting Behavior of the Advocates General at the European Court of Justice. Review of Law \& Economics 14(1).

Frankenreiter, J. (2018b, January). Informal Judicial Hierarchies: Case Assignment and Chamber Composition at the European Court of Justice. SSRN Scholarly Paper ID 2778807, Social Science Research Network, Rochester, NY.

Gabel, M. J. and J. D. Huber (2000, January). Putting Parties in Their Place: Inferring Party Left-Right Ideological Positions from Party Manifestos Data. American Journal of Political Science 44(1), 94. 
Garrett, G., R. D. Kelemen, and H. Schulz (1998). The European Court of Justice, National Governments, and Legal Integration in the European Union. International Organization 52(1), 149-176.

Gibson, J. L. and G. A. Caldeira (2011). Has Legal Realism Damaged the Legitimacy of the U.S. Supreme Court? Law 83 Society Review 45(1), 195-219.

Gibson, J. L. and M. J. Nelson (2015). Is the U.S. Supreme Court's Legitimacy Grounded in Performance Satisfaction and Ideology? American Journal of Political Science 59(1), 162-174.

Gschwend, T., S. Sternberg, and S. Zittlau (2016). Are Judges Political Animals after All? Quasi-Experimental Evidence from the German Federal Constitutional Court. In SSRN Electronic Journal, Brussels.

Hermansen, S. S. L. and D. Naurin (2019). Will do? Selecting Judges on the Basis of Policy Preferences or Performance Indicators. In ECPR Joint Sessions, Mons.

Kelemen, R. D. (2012, January). The political foundations of judicial independence in the European Union. Journal of European Public Policy 19(1), $43-58$.

Keller, H. and S. Meier (2017). Independence and Impartiality in The Judicial Trilemma. AJIL Unbound 111, 344-348.

Knight, J. and L. Epstein (1996, November). The Norm of Stare Decisis. American Journal of Political Science 40(4), 1018.

Krehbiel, K. (1992). Information and Legislative Organization. Michigan Studies in Political Analysis. Ann Arbor: University of Michigan Press. 
Larsson, O. and D. Naurin (2016). Judicial Independence and Political Uncertainty: How the Risk of Override Affects the Court of Justice of the EU. International Organization 70(2), 377-408.

Larsson, O., D. Naurin, M. Derlén, and J. Lindholm (2017, June). Speaking Law to Power: The Strategic Use of Precedent of the Court of Justice of the European Union. Comparative Political Studies 50(7), 879-907.

Lax, J. R. (2007, August). Constructing Legal Rules on Appellate Courts. American Political Science Review 101(03), 591-604.

Lax, J. R. and C. M. Cameron (2007, June). Bargaining and Opinion Assignment on the US Supreme Court. Journal of Law, Economics, and Organization 23(2), 276-302.

Lax, J. R. and K. Rader (2015, July). Bargaining Power in the Supreme Court: Evidence from Opinion Assignment and Vote Switching. The Journal of Politics 77(3), 648-663.

Long, J. S. (1997, January). Regression Models for Categorical and Limited Dependent Variables (1 edition ed.). Thousand Oaks: SAGE Publications, Inc.

Malecki, M. (2012, January). Do ECJ judges all speak with the same voice? Evidence of divergent preferences from the judgments of chambers. Journal of European Public Policy 19(1), 59-75.

Parties, H. C. (2012, August). Statute of the Court of Justice of the European Union.

Pollack, M. A. (2003). The Engines of European Integration: Delegation, Agency, and Agenda Setting in the EU. Oxford University Press.

Prechal, S. (2015). The Many Formations of the Court of Justice: 15 Years after Nice Essay. Fordham International Law Journal 39, 1273-1288. 
Saurugger, S. and F. Terpan (2017). The Court of Justice of the European Union and the Politics of Law (1 ed.). The European Union Series. London: Palgrave.

Schmidt, S. K. (2018, January). The European Court of Justice and the Policy Process. Oxford University Press.

Schmidt, V. A. (2013, March). Democracy and Legitimacy in the European Union Revisited: Input, Output and 'Throughput'. Political Studies $61(1), 2-22$.

Segal, J. A. and H. J. Spaeth (1996, November). The Influence of Stare Decisis on the Votes of United States Supreme Court Justices. American Journal of Political Science 40(4), 971.

Shepherd, J. M. (2009a). Are Appointed Judges Strategic Too? Duke Law Journal 58(7), 1589-1626.

Shepherd, J. M. (2009b, January). The Influence of Retention Politics on Judges' Voting. The Journal of Legal Studies 38(1), 169-206.

Shepsle, K. A. and B. R. Weingast (1994). Positive Theories of Congressional Institutions. Legislative Studies Quarterly 19(2), 149-179.

Spirig, J. (2019, May). Do Fewer Judges Reach Different Decisions? Evidence from a Procedural Change in Asylum Appeal Decision Making. In PluriCourts Political Science Reading Group, Oslo.

Ura, J. D. and C. M. Flink (2016, April). Experience counts: The chief justice, management tenure, and strategic behavior on the U.S. Supreme Court. Research \& Politics 3(2), 205316801664446.

Voeten, E. (2008, November). The Impartiality of International Judges: Evidence from the European Court of Human Rights. American Political Science Review 102(4), 417-433. 
Volkens, A., P. Lehmann, T. Matthieß, N. Merz, S. Regel, and B. Weßels (2017). The Manifesto Data Collection. Manifesto Project (MRG/CMP/MARPOR). Version 2017b.

Wahlbeck, P. J. (2006, June). Strategy and Constraints on Supreme Court Opinion Assignment. University of Pennsylvania Law Review 154(6), 1729.

Wøien Hansen, V. (2014, December). Incomplete information and bargaining in the EU: An explanation of first-reading non-agreements. European Union Politics 15(4), 472-495. 


\section{Appendix}

\section{Variables}

This section provides a full description of the variables found in the replication data (CJEU_choiceset.rda).

Rapporteur (binary)

(Rapporteur) indicates the judge who served as a the judge-rapporteur on a case.

Potential politicization - debated legislation (binary) (council_agenda_b) indicates cases where at least one EU secondary law is interpreted that passed at least once as a B-item on the Council's agenda. Information on affected legislation and it's adoption by the Council is retrieved from EUR-Lex.

Potential politicization - iterative interpretation of debated legislation (count)

(council_agenda_b_n) indicates the $n^{\text {th }}-$ time -1 a legislation passed as a Council B-item is interpreted by the court. The count starts at zero, so that the first time a piece passes before the Court, it is registered as 0 and so are all cases that did not involve B-items. In cases where several laws are interpreted simultaneously, the piece with the lowest count is reported.

Potential politicization - debated new legislation (binary)

(First_time_b_item_before_court) indicates cases where at least one EU secondary law is interpreted for the first time and which passed at least once as a B-item on the Council's agenda. Information on affected legislation, it's adoption by the Council and the date of previous judgments is retrieved from EUR-Lex. 
Potential politicization - diverging member state observations (binary)

(disagreement) indicates whether member state governments have expressed diverging opinions on how the Court should rule. The data is drawn from opinions expressed in member state amicus curiae briefs submitted to the Court in preliminary reference cases. The variable is drawn from two handcoded sources, depending on the time period in question.

From 1959 to 1999, information is available from the European Court of Justice Data (Carrubba and Gabel, 2011) accessible here: http:// polisci.emory.edu/home/people/carrubba_ecjd/index.html. For each issue adressed in a member state submission, the coders have identified whether the government agreed with the advocate general's opinion. I flag a disagreement between member state governments when two or more briefs are submitted and at least one government sides with the advocate general while the other does not.

From 1996 to 2007, information is available from a similar data collection (Larsson and Naurin, 2016). In this project, coders were instructed to note member states' perferred answer to each preliminary question and code them as "yes", "no" or "yes, but..." or "no, but...". I flag a disagreement between member states in cases where at least two governments have clearly expressed opposing positions on at least one question ("yes" or "no").

As illustrated in figure 5, the frequency with which member states express diverging opinions has increased over time. However, so has the number of governments entitled to file observations because of the successive EU enlargements. In the final analysis, I rely on data from 1980 and onwards. As is apparent from table 3, the two coding schemes result in different cases being flagged as "politicized". Analysis of potential time-trends (across data sets) therefore provides little information. 
In the years where the two data sets overlap, I have relied on data from the Larsson and Naurin project.

\begin{tabular}{llll}
\hline \hline & Carrubba \& Hankla: & & \\
& & Agreement & Disagreement \\
\hline Larsson \& Naurin: & Agreement & $115(78 \%)$ & $10(7 \%)$ \\
& Disagreement & $9(6 \%)$ & $14(9 \%)$
\end{tabular}

Table 3: Overlap in how disagreement between member state governments are coded between datasets.

\section{Distance from median judge (continuous)}

(abs (FreeEconomy.w.median-FreeEconomy_cur.w)) measures the absolute preference distance on economic issues between a judge's current government and the median among member states. Preferences are calculated in the following way:

In the first step, I identify the government in power at the time of the appointment decision (cabinet_current) using the "Cabinet" data provided by the ParlGov Project (Döring and Manow, 2018). In the second step, I then identify the parties in government using the "Parties" data (Döring and Manow, 2018) and link these to the manifesto data provided by the Manifesto Project (Volkens et al., 2017). In the third step, I estimate preferences (FreeEconomy_cur . w and FreeEconomy.w.median ) expressed in all party manifestoes using the vanilla method (Gabel and Huber, 2000). The indicators are questions related to the economic preferences of parties ("per401", "per402", "per403", "per404", "per405", "per406", "per409", "per410", "per412", "per413", "per414", "per415" and "per416"). Finally, in multiparty cabinets preferences are weighted according to each party's seat share in parliament.

As illustrated in Figure 4, the spread in governmental economic preferences has varied over time. 


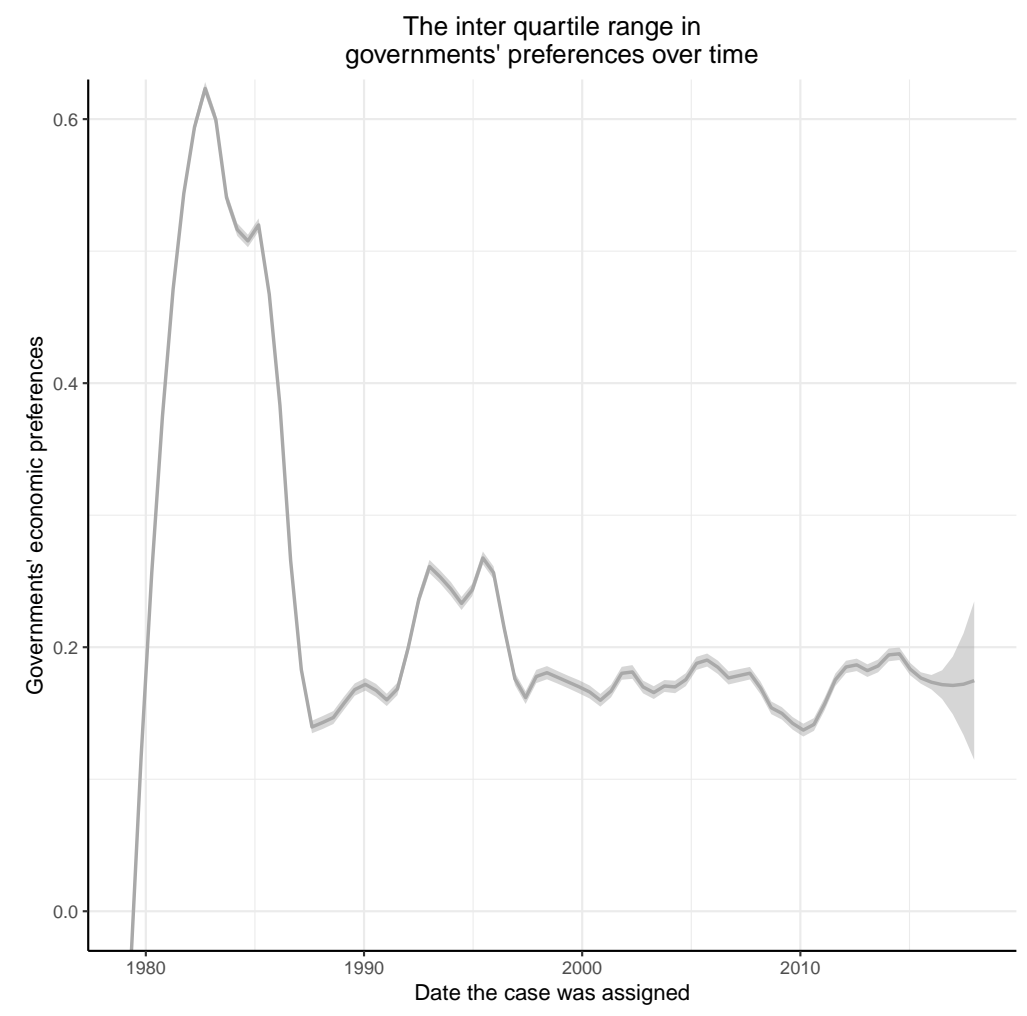

Figure 4: The spread in government preferences have varied over time. (Results from a loess estimation of the standard deviation of preferences in each choice set.) 
Membership unclear (binary)

(ExitDecisionMade == 1 | EntryDecisionNotMade == 1) indicates members whose membership at the Court is uncertain. The Court's official documents do not report the date of the rapporteur appointment. To construct the choice set, I therefore include all judges who were members of the Court at any point from the case was lodged to its' final decision. Since this is a fairly broad definition, I therefore control for situations in which the judge is unlikely to act as rapporteur. The indicator marks two situations: First, when the Council has announced the appointment of a new judge, but the judge is still a member of the Court, it is likely that the incumbent judge will not be able to see the case through. Second, the indicator marks judges who are presently members, but whose appointment was not yet made public when the allocation most likely took place.

Ties to member state - Case from judge's member state (binary) (CaseFromMS) indicates if the judge's member state is involved in the case; either as a party in a direct action or filed by a national court in an indirect action. 


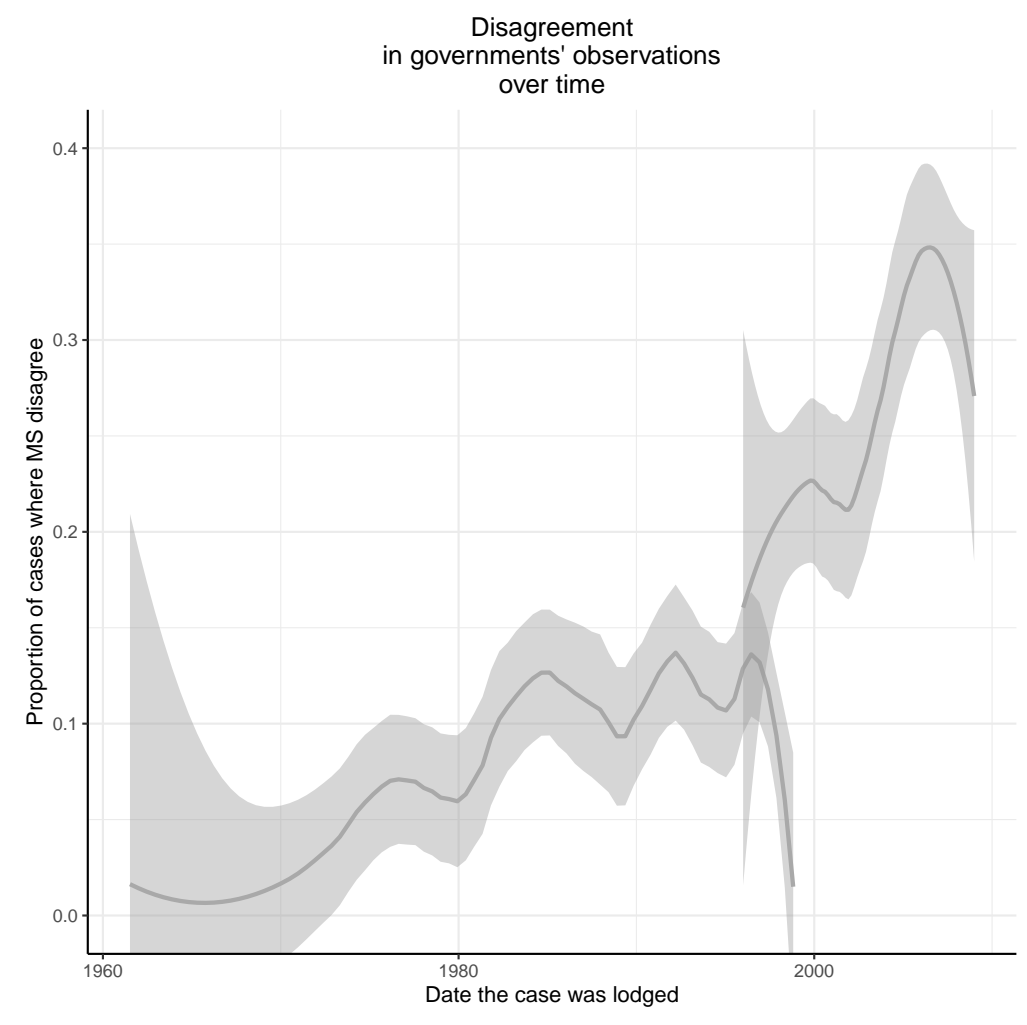

Figure 5: Proportion of the coded preliminary reference cases where member states file different opinions. 


\section{Recurring topics}

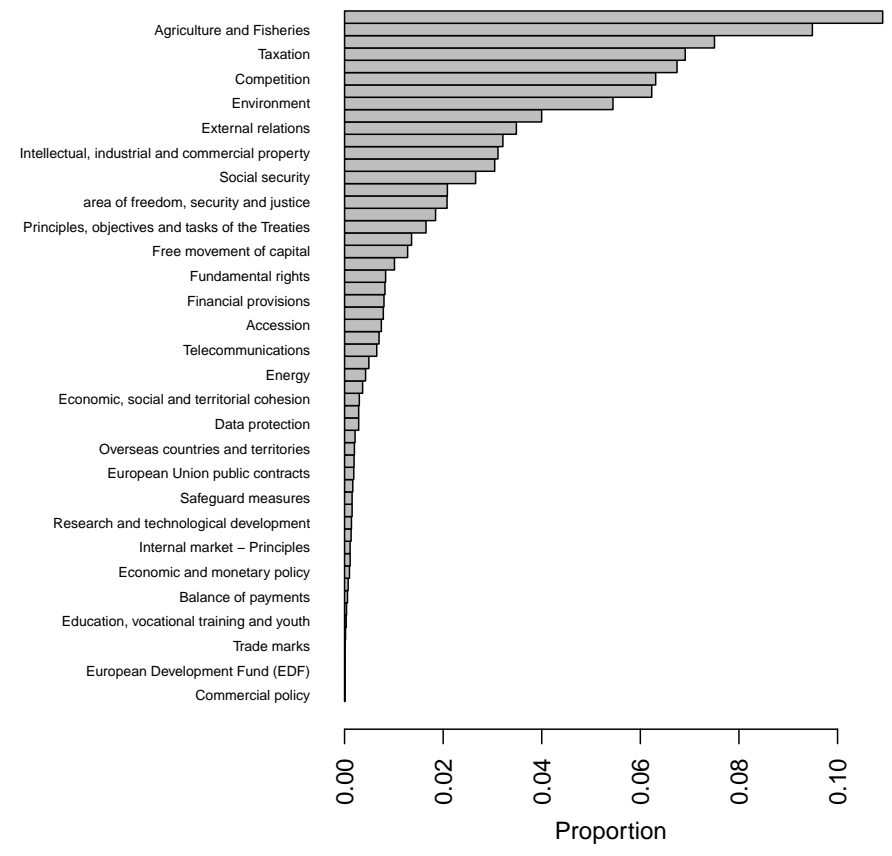

Recurring topics

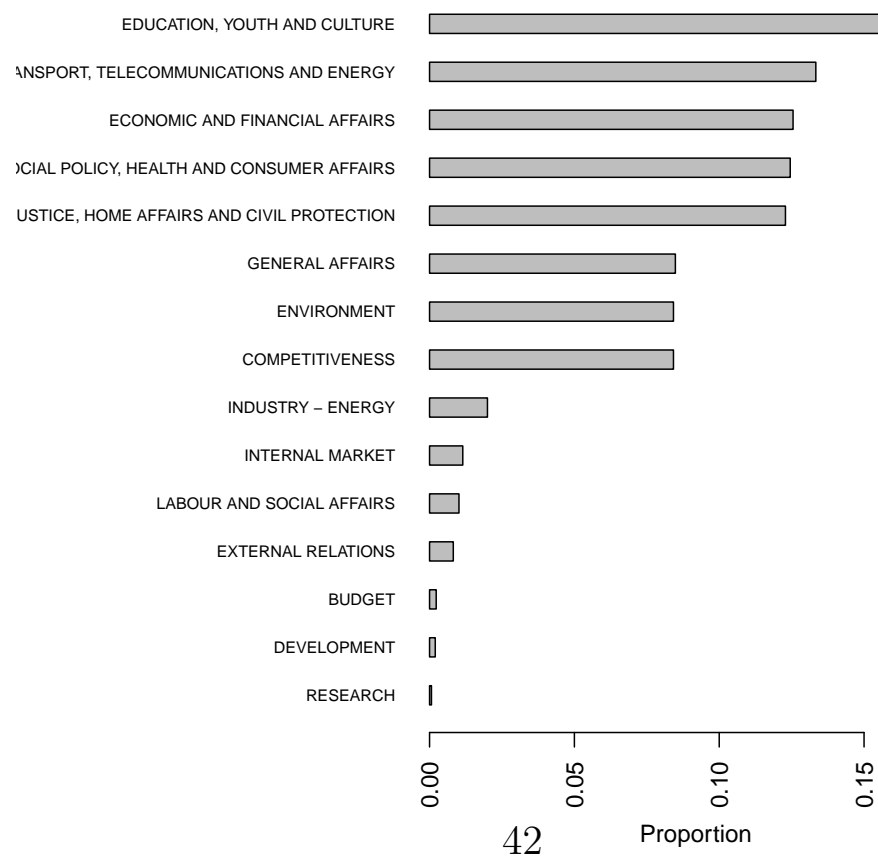

Figure 6: 


\section{Estimation strategy}

All results are obtained using MCMC simulation within a Bayesian framework. To retain a valid data sample that includes all judges in the choice set, values for some units are simulated. Most predictors do not contain missing observations. A notable exception is the measure of governmental preferences. Listwise exclusion would effectively remove judges from the President's choice set, thereby counteracting the realism implied in the conditional logit model. Instead, I impute the missing observations through a linear regression estimated in parallel to the main model. While government preferences are measured using party manifesto data (Volkens et al., 2017), the imputations rely on information on the prime minister's party family (Döring and Manow, 2018). The Bayesian framework incorporates the additional information to the model while also inserting the uncertainty implied in the imputation (?, p. 237-244). In total, depending on the model, some $7 \%$ to $8 \%$ of the observations rely on preferences imputed in this way. All models are run with 2000 iterations burn-in to ensure convergence. I then sample every tenth iteration for the subsequent 5000 iterations. 


\begin{tabular}{lc}
\hline \hline Dependent variable: 'Economic preferences' & Model 1 \\
\hline Intercept & -0.029 \\
General left-right orientation (rile) & $(-0.032,-0.026)$ \\
& 0.03 \\
Agrarian (ref. Conservative) & $-0.029,0.03)$ \\
Christian democracy (ref. Conservative) & $(-0.034,-0.018)$ \\
& -0.012 \\
Communist/Socialist (ref. Conservative) & $(-0.015,-0.009)$ \\
& -0.095 \\
Liberal (ref. Conservative) & $(-0.104,-0.086)$ \\
& 0.096 \\
no family (ref. Conservative) & $(0.092,0.099)$ \\
& -0.076 \\
Social democracy (ref. Conservative) & $(-0.086,-0.066)$ \\
& -0.073 \\
Number of observations & $(-0.075,-0.07)$ \\
\hline Median effects with 95\% HDI in parenthesis. & \\
\end{tabular}

Table 4: Estimation of government economic preferences. Results from a linear regression run in parallel to the main model used for imputations of party preferences (1980-2015).

\section{Alternative models}

\section{Effect of specialization}

Table 5 reports the results of models using different operationalizations of specialization. The all refer to the overlap between the present case and previous cases in each judge's portfolio as rapporteur. The first two columns report the effect of specialization defined as in the main text relying on 1) the number of previous cases affecting the same legislation (narrow definition) and 2) the overlap in subject matter between successive cases (broad definition). The two last columns rely on overlap in the subset of cases where I have information on the 3) Council formation that debated and/or adopted EU secondary legislation interpreted and 4) the Commission Directorate General that made the initial proposal. 


\begin{tabular}{|c|c|c|c|c|}
\hline Dependent variable: 'Allocation of report' & Model 1 & Model 2 & Model 3 & Model 4 \\
\hline Specialization (overlap in affected case(s)) & $\begin{array}{c}1.378 \\
(1.343,1.412)\end{array}$ & & & \\
\hline Specialization (EUR-Lex) & & $\begin{array}{c}0.656 \\
(0.626,0.685)\end{array}$ & & \\
\hline Specialization (Commission DG) & & & $\begin{array}{c}0.702 \\
(0.658,0.74)\end{array}$ & \\
\hline Specialization (Council formation) & & & & $\begin{array}{c}0.618 \\
(0.562,0.696)\end{array}$ \\
\hline Ties to member state (case from MS) & $\begin{array}{c}-1.45 \\
(-1.567,-1.295)\end{array}$ & $\begin{array}{c}-1.445 \\
(-1.586,-1.311)\end{array}$ & $\begin{array}{c}-1.756 \\
(-1.973,-1.534)\end{array}$ & $\begin{array}{c}-5.259 \\
(-7.904,-3.364)\end{array}$ \\
\hline Cases as rapporteur & $\begin{array}{c}-0.248 \\
(-0.271,-0.234)\end{array}$ & $\begin{array}{c}-0.48 \\
(-0.506,-0.451)\end{array}$ & $\begin{array}{c}-0.534 \\
(-0.573,-0.498)\end{array}$ & $\begin{array}{c}-0.439 \\
(-0.509,-0.389)\end{array}$ \\
\hline Membership unclear & $\begin{array}{c}-0.924 \\
(-1.023,-0.834)\end{array}$ & $\begin{array}{c}-0.982 \\
(-1.071,-0.889)\end{array}$ & $\begin{array}{c}-0.936 \\
(-1.105,-0.782)\end{array}$ & $\begin{array}{c}-1.363 \\
(-1.669,-1.013)\end{array}$ \\
\hline Participation & $\begin{array}{c}0.045 \\
(0.042,0.047)\end{array}$ & $\begin{array}{c}0.045 \\
(0.043,0.048)\end{array}$ & $\begin{array}{c}0.036 \\
(0.032,0.04)\end{array}$ & $\begin{array}{c}0.025 \\
(0.019,0.032)\end{array}$ \\
\hline Leadership (Chamber/Vice president) & $\begin{array}{c}-0.489 \\
(-0.563,-0.416)\end{array}$ & $\begin{array}{c}-0.542 \\
(-0.628,-0.469)\end{array}$ & $\begin{array}{c}-0.613 \\
(-0.73,-0.489)\end{array}$ & $\begin{array}{c}-0.348 \\
(-0.463,-0.212)\end{array}$ \\
\hline Number of observations & 217284 & 217284 & 96465 & 50785 \\
\hline Number of choice sets & 9949 & 9949 & 4377 & 1862 \\
\hline Proportion of correct predictions & 0.65 & 0.597 & 0.604 & 0.565 \\
\hline Prop. of correct positive pred. & 0.613 & 0.643 & 0.637 & 0.627 \\
\hline Prop. of correct negative pred. & 0.652 & 0.594 & 0.602 & 0.563 \\
\hline
\end{tabular}

Median effects with $95 \%$ symmetric posterior density interval in parenthesis.

Table 5: The effect of EXPERTISE on allocation of court cases, regardless of the procedure in question. Results from a hierarchical conditional logit.

\section{Effect of government preferences}

This section explores alternative ways of modelling the conditional effect of political preferences.

Different domestic principals The analysis in the main text assumes that the presidents seeks to align judges' career incentives with the Court's interest to appear as apolitical and unbiased. The argument is that all judges may be suspected of being under pressure from their government to rule in the government's preferred direction. In cases that divide governments, the president therefore prefers a rapporteur who does not risk being under pressure to promote an extreme position.

Since judges sit for renewable terms and their reappointment is condi- 
tional on renomination by the national government, we may expect that the president considers the current government to be judge's main principal. In the main analysis, I therefore rely on on a measure of the current governmental parties' preferences weighted by each coalition party's relative size in parliament (Table 6). As an alternative operationalization, in Table 7 I report the results from an unweighted average of the governmental parties' preferences. Results remain largely the same: While the estimated effect on allocation when weighing coalition parties according to their size is larger, so is the uncertainty surrounding the estimate. Both variables make an assumption about the expectations judges can reasonably have as to who will be their primary domestic gatekeepers to reselection. The parties currently in power may not be the ones that finally make the reappointment decision. However it is the judge's (as well as the president's and other member states') best guess at the time of the case allocation.

An alternative explanation is that governments use their power of nomination to send judges to Luxembourg whose political preferences are aligned with their own and that the president seeks to obtain a moderate outcome by considering the judges' whose preferences are similarly moderate. In such a scenario, we could consider the appointing government's preferences to be indicative of the president's case allocations. This is what I do in Table 8. Quite often, the appoitning and current government are the same. As is apparent from comparing results across tables, the effect of preferences in both operationalizations of politicization is larger and different from zero when considering the current government's political orientation rather than that of the appointing government. 


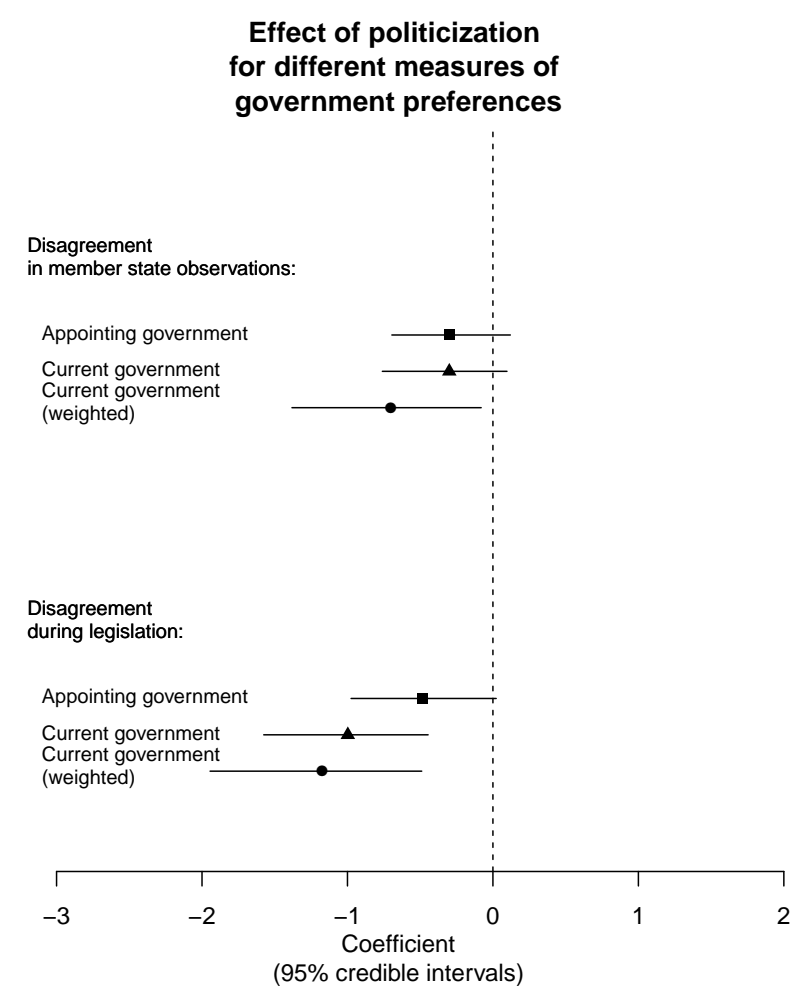

Figure 7: Alternative ways of measuring governmental preferences: Results from models in columns 1 and 2 reported in Tables 6, 7 and 8 . 


\begin{tabular}{|c|c|c|c|c|}
\hline Dependent variable: 'Allocation of report' & $1980-2015$ & 1980-2008 & 1980-1999 & 1996-2008 \\
\hline Distance from median government & 0.094 & 0.182 & 0.091 & 0.178 \\
\hline Distance from median government $*$ Debated new legislation $(\mathrm{H} 2 \mathrm{a})$ & $\begin{array}{c}(-0.096,0.274) \\
-1.173 \\
(-1.846,-0.652)\end{array}$ & $(-0.003,0.337)$ & $(-0.08,0.278)$ & $(-0.147,0.599)$ \\
\hline Distance from median government $*$ Disagreement MS observations (H2a) & & $\begin{array}{c}-0.702 \\
(-1.329,-0.175)\end{array}$ & $\begin{array}{c}-0.437 \\
(-0.974 .0 .078)\end{array}$ & $\begin{array}{c}-1.391 \\
(-2.307,-0.446)\end{array}$ \\
\hline Specialization (overlap in affected cases) & $\begin{array}{c}1.529 \\
(1.477,1.576)\end{array}$ & $\begin{array}{c}1.092 \\
(1.042,1.146)\end{array}$ & $\begin{array}{c}1.023 \\
(0.932,1.12)\end{array}$ & $\begin{array}{c}1.19 \\
(1.09,1.28)\end{array}$ \\
\hline Specialization (overlap in topics) & $\begin{array}{c}0.301 \\
(0.253,0.346)\end{array}$ & $\begin{array}{c}0.215 \\
(0.156,0.281)\end{array}$ & $\begin{array}{c}0.18 \\
(0.093,0.254)\end{array}$ & $\begin{array}{c}0.275 \\
(0.199,0.361)\end{array}$ \\
\hline Past cases & $\begin{array}{c}-0.502 \\
(-0.539,-0.465)\end{array}$ & $\begin{array}{c}-0.414 \\
(-0.463,-0.368)\end{array}$ & $\begin{array}{c}-0.439 \\
(-0.514,-0.373)\end{array}$ & $\begin{array}{c}-0.415 \\
(-0.482,-0.341)\end{array}$ \\
\hline Membership unclear & $\begin{array}{c}-1.169 \\
(-1.297,-1.052)\end{array}$ & $\begin{array}{c}-1.167 \\
(-1.331,-0.99)\end{array}$ & $\begin{array}{c}-0.947 \\
(-1.185,-0.731)\end{array}$ & $\begin{array}{c}-1.608 \\
(-1.884,-1.319)\end{array}$ \\
\hline Participation & $\begin{array}{c}0.047 \\
(0.043,0.05)\end{array}$ & $\begin{array}{c}0.051 \\
(0.047 .0 .056)\end{array}$ & $\begin{array}{c}0.051 \\
(0.045,0.056)\end{array}$ & $\begin{array}{c}0.052 \\
(0.046 .0 .058)\end{array}$ \\
\hline Leadership (President) & $\begin{array}{c}-0.602 \\
(-0.686,-0.488)\end{array}$ & $\begin{array}{c}-0.614 \\
(-0.8,-0.408)\end{array}$ & & $\begin{array}{c}-0.693 \\
(-0.909,-0.498)\end{array}$ \\
\hline Number of observations & 118247 & 60080 & 25246 & 37094 \\
\hline Proportion of correct predictions & 0.702 & 0.66 & 0.657 & 0.665 \\
\hline Prop. of correct positive pred. & 0.643 & 0.621 & 0.562 & 0.684 \\
\hline Prop. of correct negative pred. & 0.705 & 0.662 & 0.665 & 0.665 \\
\hline
\end{tabular}

Table 6: The effect of the CURRENT government's WEIGHTED preferences on allocation of preliminary reference cases. Results from a hierarchical conditional logit.

\begin{tabular}{|c|c|c|c|c|}
\hline Dependent variable: 'Allocation of report' & $1980-2015$ & $1980-2008$ & 1980-1999 & $1996-2008$ \\
\hline Distance from median government & $\begin{array}{c}0.059 \\
(-0.082,0.193)\end{array}$ & $\begin{array}{c}0.111 \\
(-0.008,0.267)\end{array}$ & $\begin{array}{c}-0.016 \\
(-0.187,0.157)\end{array}$ & $\begin{array}{c}0.359 \\
(0.125,0.567)\end{array}$ \\
\hline Distance from median government $*$ Debated new legislation $(\mathrm{H} 2 \mathrm{a})$ & $\begin{array}{c}-0.998 \\
(-1.436,-0.541)\end{array}$ & & & \\
\hline Distance from median government $*$ Disagreement MS observations $(\mathrm{H} 2 \mathrm{a})$ & & $\begin{array}{c}-0.3 \\
(-0.725,0.054)\end{array}$ & $\begin{array}{c}-0.424 \\
(-0.932,0.096)\end{array}$ & $\begin{array}{c}-0.475 \\
(-0.979,-0.005)\end{array}$ \\
\hline Specialization (overlap in affected cases) & $\begin{array}{c}1.533 \\
(1.487,1.581)\end{array}$ & $\begin{array}{c}1.095 \\
(1.035,1.163)\end{array}$ & $\begin{array}{c}1.023 \\
(0.936,1.098)\end{array}$ & $\begin{array}{c}1.186 \\
(1.095,1.268)\end{array}$ \\
\hline Specialization (overlap in topics) & $\begin{array}{c}0.298 \\
(0.25,0.347)\end{array}$ & $\begin{array}{c}0.221 \\
(0.155,0.277)\end{array}$ & $\begin{array}{c}0.168 \\
(0.084,0.256)\end{array}$ & $\begin{array}{c}0.273 \\
(0.195,0.357)\end{array}$ \\
\hline Ties to member state (Case from MS) & $\begin{array}{c}-1.867 \\
(-2.111,-1.628)\end{array}$ & $\begin{array}{c}-1.072 \\
(-1.229,-0.891)\end{array}$ & $\begin{array}{c}-0.726 \\
(-0.885,-0.537)\end{array}$ & $\begin{array}{c}-2.655 \\
(-3.322,-2.102)\end{array}$ \\
\hline Past cases & $\begin{array}{c}-0.505 \\
(-0.543,-0.467)\end{array}$ & $\begin{array}{c}-0.415 \\
(-0.467,-0.366)\end{array}$ & $\begin{array}{c}-0.436 \\
(-0.503,-0.363)\end{array}$ & $\begin{array}{c}-0.414 \\
(-0.489,-0.349)\end{array}$ \\
\hline Membership unclear & $\begin{array}{c}-1.188 \\
(-1.32,-1.04)\end{array}$ & $\begin{array}{c}-1.171 \\
(-1.356,-0.987)\end{array}$ & $\begin{array}{c}-0.961 \\
(-1.186,-0.701)\end{array}$ & $\begin{array}{c}-1.577 \\
(-1.881,-1.306)\end{array}$ \\
\hline Participation & $\begin{array}{c}0.047 \\
(0.043,0.05)\end{array}$ & $\begin{array}{c}0.052 \\
(0.048,0.056)\end{array}$ & $\begin{array}{c}0.049 \\
(0.044,0.055)\end{array}$ & $\begin{array}{c}0.052 \\
(0.046,0.057)\end{array}$ \\
\hline Leadership (President) & $\begin{array}{c}-0.598 \\
(-0.704,-0.496)\end{array}$ & $\begin{array}{c}-0.598 \\
(-0.787,-0.385)\end{array}$ & & $\begin{array}{c}-0.642 \\
(-0.823,-0.448)\end{array}$ \\
\hline Number of observations & 118161 & 60080 & 25246 & 37094 \\
\hline Number of choice sets & 5012 & 3286 & 1823 & 1611 \\
\hline Proportion of correct predictions & 0.702 & 0.66 & 0.657 & 0.666 \\
\hline Prop. of correct positive pred. & 0.641 & 0.619 & 0.564 & 0.682 \\
\hline Prop. of correct negative pred. & 0.705 & 0.662 & 0.665 & 0.665 \\
\hline
\end{tabular}

Median effects with 95\% HDI in parenthesis.

Table 7: The effect of the CURRENT government's preferences on allocation of preliminary reference cases. Results from a hierarchical conditional logit. 


\begin{tabular}{|c|c|c|c|c|}
\hline Dependent variable: 'Allocation of report' & $1980-2015$ & $1980-2008$ & 1980-1999 & 1996-2008 \\
\hline Distance from median government & -0.008 & 0.069 & 0.014 & -0.093 \\
\hline Distance from median government $*$ Debated new legislation $(\mathrm{H} 2 \mathrm{a})$ & $\begin{array}{c}(-0.144,0.125) \\
-0.483 \\
(-0.892,-0.048)\end{array}$ & $(-0.089,0.2)$ & $(-0.148,0.197)$ & $(-0.34,0.141)$ \\
\hline Distance from median government $*$ Disagreement MS observations $(\mathrm{H} 2 \mathrm{a})$ & & $\begin{array}{c}-0.301 \\
(-0.617,0.082)\end{array}$ & $\begin{array}{c}0.039 \\
(-0.344,0.488)\end{array}$ & $\begin{array}{c}-0.551 \\
(-0.94,-0.037)\end{array}$ \\
\hline Specialization (overlap in affected cases) & $\begin{array}{c}1.532 \\
(1.484,1.582)\end{array}$ & $\begin{array}{c}1.106 \\
(1.045,1.157)\end{array}$ & $\begin{array}{c}1.036 \\
(0.961,1.113)\end{array}$ & $\begin{array}{c}1.177 \\
(1.103,1.286)\end{array}$ \\
\hline Specialization (overlap in topics) & $\begin{array}{c}0.3 \\
(0.259,0.344)\end{array}$ & $\begin{array}{c}0.221 \\
(0.16,0.273)\end{array}$ & $\begin{array}{c}0.175 \\
(0.099,0.241)\end{array}$ & $\begin{array}{c}0.287 \\
(0.195,0.364)\end{array}$ \\
\hline Ties to member state (Case from MS) & $\begin{array}{c}-1.86 \\
(-2.103,-1.61)\end{array}$ & $\begin{array}{c}-1.063 \\
(-1.24,-0.895)\end{array}$ & $\begin{array}{c}-0.713 \\
(-0.904,-0.534)\end{array}$ & $\begin{array}{c}-2.725 \\
(-3.318,-2.159)\end{array}$ \\
\hline Past cases & $\begin{array}{c}-0.505 \\
(-0.543,-0.472)\end{array}$ & $\begin{array}{c}-0.42 \\
(-0.473,-0.371)\end{array}$ & $\begin{array}{c}-0.441 \\
(-0.503,-0.363)\end{array}$ & $\begin{array}{c}-0.422 \\
(-0.492,-0.354)\end{array}$ \\
\hline Membership unclear & $\begin{array}{c}-1.181 \\
(-1.319,-1.039)\end{array}$ & $\begin{array}{c}-1.173 \\
(-1.347,-1.001)\end{array}$ & $\begin{array}{c}-0.935 \\
(-1.144,-0.724)\end{array}$ & $\begin{array}{c}-1.612 \\
(-1.913,-1.31)\end{array}$ \\
\hline Participation & $\begin{array}{c}0.047 \\
(0.043,0.05)\end{array}$ & $\begin{array}{c}0.052 \\
(0.048,0.055)\end{array}$ & $\begin{array}{c}0.05 \\
(0.044,0.057)\end{array}$ & $\begin{array}{c}0.052 \\
(0.047,0.058)\end{array}$ \\
\hline Leadership (President) & $\begin{array}{c}-0.593 \\
(-0.697,-0.497)\end{array}$ & $\begin{array}{c}-0.598 \\
(-0.78,-0.431)\end{array}$ & & $\begin{array}{c}-0.677 \\
(-0.884,-0.51)\end{array}$ \\
\hline Number of observations & 118161 & 60080 & 25246 & 37094 \\
\hline Number of choice sets & 5012 & 3286 & 1823 & 1611 \\
\hline Proportion of correct predictions & 0.702 & 0.66 & 0.658 & 0.665 \\
\hline Prop. of correct positive pred. & 0.641 & 0.618 & 0.564 & 0.684 \\
\hline Prop. of correct negative pred. & 0.704 & 0.663 & 0.666 & 0.665 \\
\hline
\end{tabular}

Median effects with 95\% HDI in parenthesis.

Table 8: The effect of the APPOINTING government's preferences on allocation of preliminary reference cases. Results from a hierarchical conditional logit. 
The total effect of preferences in politicized cases The main models report the size and precision of the difference in effect of preferences between politicized and non-politicized cases (i.e.: the interaction term). However, since the effect of preferences in non-politicized cases is estimated with uncertainty, the total effect of preferences in politicized cases also remains uncertain. To verify that the negative effect of extreme preferences is in itself significant in politicized cases, I therefore run models on the subset of cases that have been classified as "politicized". As is apparent from the results reported in in Table 9, the effect of the current government's weighted preferences not only remains in the expected direction, but are also estimated as different from zero.

\begin{tabular}{lcc}
\hline \hline Dependent variable: 'Allocation of report' & Only B-items & Only MS disagreement \\
\hline Distance from median government & -1.02 & -0.489 \\
& $(-1.499,-0.454)$ & $(-0.963,-0.062)$ \\
Specialization (overlap in affected cases) & 2.434 & 1.045 \\
& $(2.108,2.782)$ & $(0.921,1.185)$ \\
Specialization (overlap in topics) & 0.336 & 0.224 \\
& $(0.191,0.473)$ & $(0.097,0.359)$ \\
Ties to member state (Case from MS) & -2.584 & -1.459 \\
& $(-3.906,-1.694)$ & $(-2.097,-1.046)$ \\
Past cases & -0.375 & -0.323 \\
& $(-0.503,-0.26)$ & $(-0.436,-0.214)$ \\
Membership unclear & -1.009 & -1.266 \\
& $(-1.442,-0.682)$ & $(-1.709,-0.841)$ \\
Participation & 0.037 & 0.048 \\
& $(0.027,0.05)$ & $(0.039,0.058)$ \\
Leadership (President) & -0.188 & -0.385 \\
& $(-0.483,0.093)$ & $(-0.757,-0.088)$ \\
Number of observations & 10716 & 12779 \\
Number of choice sets & 465 & 613 \\
Proportion of correct predictions & & 0.659 \\
Prop. of correct positive pred. & 0.62 & 0.669 \\
Prop. of correct negative pred. & 0.581 & 0.659 \\
\hline Median effects with 95\% HDI in parenthesis. & 0.621 & \\
\hline
\end{tabular}

Table 9: Considering only politicized cases: The effect of the current government's weighted preferences on allocation of preliminary reference cases. Results from a hierarchical conditional logit. 


\begin{tabular}{|c|c|c|c|}
\hline Dependent variable: 'Allocation of report' & Current gvt. weighted & Current gvt. & Appointing gvt. \\
\hline \multirow[t]{2}{*}{ Distance from median government } & 0.245 & 0.095 & 0.185 \\
\hline & $(0.029,0.44)$ & $(-0.101,0.249)$ & $(-0.014,0.355)$ \\
\hline Distance from median government $*$ Debated new legislation $(\mathrm{H} 2 \mathrm{a})$ & $\begin{array}{c}-1.15 \\
(-1.709,-0.56)\end{array}$ & $\begin{array}{c}-0.804 \\
(-1.225,-0.374)\end{array}$ & $\begin{array}{c}-0.606 \\
(-1023-0.227)\end{array}$ \\
\hline \multirow[t]{2}{*}{ Distance from median government ${ }^{*}$ Iteration before the court $(\mathrm{H} 2 \mathrm{~b})$} & 0.133 & 0.109 & 0.031 \\
\hline & $(0.041,0.228)$ & $(0.03,0.186)$ & $(-0.03,0.096)$ \\
\hline \multirow[t]{2}{*}{ Specialization (overlap in affected cases) } & 1.536 & 1.53 & 1.534 \\
\hline & $(1.485,1.58)$ & $(1.493,1.585)$ & $(1.485,1.579)$ \\
\hline \multirow[t]{2}{*}{ Specialization (overlap in topics) } & 0.299 & 0.3 & 0.302 \\
\hline & $(0.265,0.341)$ & $(0.252,0.338)$ & $(0.258,0.346)$ \\
\hline \multirow{2}{*}{ Ties to member state (Case from MS) } & -1.892 & -1.875 & -1.883 \\
\hline & $(-2.13,-1.647)$ & $(-2.168,-1.666)$ & $(-2.142,-1.612)$ \\
\hline \multirow[t]{2}{*}{ Past cases } & -0.506 & -0.505 & -0.509 \\
\hline & $(-0.546,-0.467)$ & $(-0.543,-0.463)$ & $(-0.545,-0.47)$ \\
\hline \multirow[t]{2}{*}{ Membership unclear } & -1.193 & -1.169 & -1.195 \\
\hline & $(-1.313,-1.039)$ & $(-1.318,-1.016)$ & $(-1.316,-1.059)$ \\
\hline \multirow{2}{*}{ Participation } & 0.047 & 0.047 & 0.047 \\
\hline & $(0.043,0.05)$ & $(0.044,0.05)$ & $(0.044,0.05)$ \\
\hline \multirow[t]{2}{*}{ Leadership (Chamber/vice president) } & -0.596 & -0.589 & -0.595 \\
\hline & $(-0.692,-0.485)$ & $(-0.694,-0.488)$ & $(-0.694,-0.506)$ \\
\hline Number of observations & 118247 & 118247 & 118247 \\
\hline Number of choice sets & 5015 & 5015 & 5015 \\
\hline Proportion of correct predictions & 0.702 & 0.701 & 0.702 \\
\hline Prop. of correct positive pred. & 0.641 & 0.642 & 0.64 \\
\hline Prop. of correct negative pred. & 0.705 & 0.704 & 0.705 \\
\hline
\end{tabular}

Median effects with $95 \%$ HDI in parenthesis.

Table 10: The effect of government's preferences on allocation of preliminary reference cases in instances with DISAGREEMENT between MS during LEGISLATION). Results from a hierarchical conditional logit.

\section{Are the effects only driven by certain presidencies?}

Since allocation decisions are left to the Court president's discretion, it may be that the results reported in the main paper are driven by the idiosyncratic selection criteria of one (or a few) president(s). This is a risk because the Court's case-load has grown over time and some presidents have sat for longer periods than others. To verify that the main findings are robust to the individual presidents' personae, I have therefore run separate models for each of the six Court presidents since 1980. In these models, I test the (additive) effects of specialization and the effect of government preferences in cases involving new secondary legislation which was subject to a political debate 
in the Council. Results are reported in Tables 11 and 12.

\begin{tabular}{|c|c|c|c|}
\hline Dependent variable: 'Allocation of report' & Wilmars & Stuart & Due \\
\hline Distance from median government & $\begin{array}{c}-0.865 \\
(-1.777,0.066)\end{array}$ & $\begin{array}{c}0.507 \\
(-0.153,1.027)\end{array}$ & $\begin{array}{c}0.27 \\
(-0.143,0.745)\end{array}$ \\
\hline Distance from median government $*$ Debated new legislation & $\begin{array}{c}-2.879 \\
(-5.582,-0.722)\end{array}$ & $\begin{array}{c}-1.88 \\
(-4.002,-0.074)\end{array}$ & $\begin{array}{c}-3.059 \\
(-4.84,-1.511)\end{array}$ \\
\hline Specialization (overlap in affected cases) & $\begin{array}{c}1.683 \\
(1.209,2.115)\end{array}$ & $\begin{array}{c}1.802 \\
(1.52,2.095)\end{array}$ & $\begin{array}{c}2.086 \\
(1.912,2.249)\end{array}$ \\
\hline Specialization (overlap in topics) & $\begin{array}{c}-0.863 \\
(-1.217,-0.442)\end{array}$ & $\begin{array}{c}0.033 \\
(-0.202,0.251)\end{array}$ & $\begin{array}{c}-0.225 \\
(-0.389,-0.061)\end{array}$ \\
\hline Ties to member state (Case from MS) & $\begin{array}{c}-1.12 \\
(-1.9,-0.428)\end{array}$ & $\begin{array}{c}-0.581 \\
(-1.133,-0.126)\end{array}$ & $\begin{array}{c}-0.866 \\
(-1.267,-0.556)\end{array}$ \\
\hline Past cases & $\begin{array}{c}0.586 \\
(0.195,1.032)\end{array}$ & $\begin{array}{c}-0.346 \\
(-0.553,-0.152)\end{array}$ & $\begin{array}{c}-0.32 \\
(-0.477,-0.16)\end{array}$ \\
\hline Membership unclear & $\begin{array}{c}0.044 \\
(-0.925,0.905)\end{array}$ & $\begin{array}{c}-1.095 \\
(-1.723,-0.665)\end{array}$ & $\begin{array}{c}-1.397 \\
(-1.826,-0.979)\end{array}$ \\
\hline Participation & $\begin{array}{c}0.019 \\
(-0.005,0.042)\end{array}$ & $\begin{array}{c}0.053 \\
(0.037,0.07)\end{array}$ & $\begin{array}{c}0.061 \\
(0.049,0.075)\end{array}$ \\
\hline Number of observations & 944 & 3071 & 6906 \\
\hline Number of choice sets & 81 & 224 & 469 \\
\hline Proportion of correct predictions & 0.695 & 0.709 & 0.718 \\
\hline Prop. of correct positive pred. & 0.58 & 0.58 & 0.646 \\
\hline Prop. of correct negative pred. & 0.706 & 0.719 & 0.723 \\
\hline
\end{tabular}

Table 11: Separate models for each presidency: Mertens de Wilmars (19801984), Stuart (1984-1988) and Due (1988-1990). Results from a hierarchical conditional logit. 


\begin{tabular}{|c|c|c|c|}
\hline Dependent variable: 'Allocation of report' & Iglesias & Skouris & Lenaerts \\
\hline Distance from median government & $\begin{array}{c}-0.051 \\
(-0.334 .0 .249)\end{array}$ & $\begin{array}{c}-0.027 \\
(-0.312,0.317)\end{array}$ & $\begin{array}{c}0.334 \\
(-0.674 .1 .128)\end{array}$ \\
\hline Distance from median government $*$ Debated new legislation & $\begin{array}{c}-0.213 \\
(-1.063,0.66)\end{array}$ & $\begin{array}{c}-0.992 \\
(-2.079-0.019)\end{array}$ & $\begin{array}{c}-2.829 \\
(-65)\end{array}$ \\
\hline Specialization (overlap in affected cases) & $\begin{array}{c}1.561 \\
(1.465,1.653)\end{array}$ & $\begin{array}{c}1.429 \\
(1.362,1.479)\end{array}$ & $\begin{array}{c}1.542 \\
(1.373,1.73)\end{array}$ \\
\hline Specialization (overlap in topics) & $\begin{array}{c}0.263 \\
(0.163,0.352)\end{array}$ & $\begin{array}{c}0.406 \\
(0.349,0.461)\end{array}$ & $\begin{array}{c}0.622 \\
(0.452,0.775)\end{array}$ \\
\hline Ties to member state (Case from MS) & $\begin{array}{c}-2.887 \\
(-3.689,-2.215)\end{array}$ & $\begin{array}{c}-5.891 \\
(-8.732,-3.983)\end{array}$ & $\begin{array}{c}-4.202 \\
(-7.414,-1.952)\end{array}$ \\
\hline Past cases & $\begin{array}{c}-0.462 \\
(-0.537,-0.38)\end{array}$ & $\begin{array}{c}-0.568 \\
(-0.614,-0.517)\end{array}$ & $\begin{array}{c}-0.681 \\
(-0.913,-0.459)\end{array}$ \\
\hline Membership unclear & $\begin{array}{c}-0.604 \\
(-0.819,-0.415)\end{array}$ & $\begin{array}{c}-1.577 \\
(-1.83,-1.358)\end{array}$ & $\begin{array}{c}-3.33 \\
(-6.486,-0.632)\end{array}$ \\
\hline Participation & $\begin{array}{c}0.055 \\
(0.05,0.06)\end{array}$ & $\begin{array}{c}0.04 \\
(0.035,0.045)\end{array}$ & $\begin{array}{c}0.004 \\
(-0.02,0.023)\end{array}$ \\
\hline Leadership (Chamber/vice president) & & $\begin{array}{c}-0.612 \\
(-0.71,-0.503)\end{array}$ & $\begin{array}{c}0.171 \\
(-0.061,0.397)\end{array}$ \\
\hline Number of observations & 22645 & 81828 & 9185 \\
\hline Number of choice sets & 1251 & 2877 & 337 \\
\hline Proportion of correct predictions & 0.709 & 0.696 & 0.758 \\
\hline Prop. of correct positive pred. & 0.665 & 0.649 & 0.653 \\
\hline Prop. of correct negative pred. & 0.711 & 0.698 & 0.762 \\
\hline
\end{tabular}

Median effects with 95\% HDI in parenthesis.

Table 12: Separate models for each presidency: Iglesias (1994-2003), Skouris (2003-2015), Lenaerts (2015-2017). Results from a hierarchical conditional logit. 